\title{
Planlama Perspektifinden Orman Sınırı Dışına Çıkatılan Alanlar Sorunu: İstanbul Örneği
}

\author{
The Issue of The Areas That are Removed Outside the Forest Boundaries \\ From the Planning Perspective: Istanbul Case
}

\section{Pelin Pınar Giritlioğlu}

İstanbul Üniversitesi Siyasal Bilgiler Fakültesi, Siyaset Bilimi ve Kamu Yönetimi Bölümü, Kentleşme ve Çevre Sorunları Anabilim Dalı, İstanbul

\section{ÖZ}

Ülkemizde orman sınırı dışına çıkartılan alanlar sorunu giderek kronik hale gelmekte, kentleri, kentlerin doğal yaşam alanlarını, ekosistemleri ciddi biçimde tehdit etmektedir. 1980 sonrası dönemde hızlanan ve 2000 sonrası dönemde kapitalist üretim ilişkilerinin, kentsel rantın ve hızla güçlenip, siyasetin içinde de kendine yaşam alanı açan sermayenin baskı ve talepleri doğrultusunda orman sınırı dışına çıkarma ve bu alanlara herhangi bir kent toprağı olarak yaklaşmak suretiyle büyük inşaat firmalarına pazarlama politikasına dönüşen bu süreç, bu alanların etraflıca tartışılması gereksinmesini de beraberinde getirmiştir. Bu tartışmaların en tepesinde de orman sınırı dışına çıkartılan alanlarda nasıl bir planlama yaklaşımı geliştirilmesi gerektiği meselesi yer almaktadır. Sorun kronik olduğu gibi, çok boyutludur ve teknik olduğu kadar, ekonomik, sosyal, etik ve politik boyutlarıyla da tartışılmayı hak etmektedir. Bu alanlardaki el değiştirme süreçleri, mülkiyet hakları sorunu, ortaya çıkan rantın paylaşımı gibi konular, konunun geriye dönük çok boyutlu bir bakış açısıyla ele alınmasını gerekli kılmaktadır. Bu çalışmanın amacı, ülkemizin kamusal malları arasında en üst sıralarda yer alan orman alanlarımızda yaşanan ve gerek yasal açıdan, gerek planlama açısından kalıcı bir soruna dönüşen orman sınırı dışına çıkartılmış alanlardaki yapılaşma sürecini yasal, politik ve ekonomik geri planıyla birlikte ele alarak ve konuyu İstanbul üzerinden tartışarak, bu alanlara yönelik bir planlama yaklaşımı geliştirmektir.

Anahtar sözcükler: Orman sınıı dışına çıkartılmış alanlar; planlama; 2/B.

\section{ABSTRACT}

The issue of the areas that are removed outside the forest boundaries continue to become a chronic problem that threatens the cities, natural life spaces in the cities, and the ecosystems. Started to speed up after the 80's, in post-2000's, this process has transformed into a marketing policy of major construction firms, as removing areas outside the forest boundaries according to the demands and pressures of capitalist production relations, urban unearned incomes, and the capital that rapidly got stronger and opened up a life space for itself in the politics; and as approaching these areas as any other urban area. Eventually, this situation arose the need of an extensive discussion about the issue. One of the most important points of this discussion is the question of what kind of a planning approach must be developed for the areas that are removed outside the forest boundary. As much as it is a chronic and multi-dimensional conflict, it also deserves to be elaborated as a technical, economical, social, ethical and political issue. The transaction processes, problems of property rights, and distribution of the unearned incomes require a multi-dimensional and retrospective perspective on the issue. The purpose of this study is to elaborate the issue of construction processes conducted in the areas that are removed outside the boundaries of the forest areas, which are actually located in the top degrees amongst the public properties of our country. It aims to develop a planning approach for these construction processes, which become a chronical problem for both the planning and the legal aspects, over the Istanbul case by discussing the legal, political and economical backgrounds. Keywords: Areas that are removed outside the forest boundaries; planning; 2/B. 


\section{Giriş}

Ülkemizde orman sınırı dı̧ına çıkartılmış alanlar konusuna, uzun yıllardan bu yana çözüm bulunamadığı gibi, bu alanlar politik ve ekonomik nedenlerle daha da kalıcı bir sorun haline gelmiştir. Konunun geri planının, orman alanları içindeki mülkiyet haklarıyla başladığı söylenebilir. Gülöksüz (20I0), son yüz elli yılda bu araziler üzerindeki mülkiyet haklarını üç ana dönüm noktasına ayırarak incelemektedir. Ona göre birinci dönüm noktası, bireysel mülkiyet haklarının kurumsallaştı̆ı̆ ve özellikle kolonilerdeki tropikal ormanlarda devlet mülkiyeti ilkesinin ön plana çıtığı 19. yy ortaları, ikinci dönüm noktası, orman ekosistemlerinde mülkiyet haklarının yalnız sermaye birikiminin sürdürülebilirliği değil, aynı zamanda ekolojik dengenin sürdürülebilirliği çerçevesinde müzakere edildiği 20. yy ortaları ve üçüncü dönüm noktası ise, orman ekosistemlerinde doğal kaynağa dayalı sermaye birikim sürecinde devletin oynadığı rolün ve emeğin denetlenme biçimlerinin radikal olarak dönüştüğü 1980 sonrasıdır.

Ülkemiz ormanlarının sınırlandırılması işlemleri 6831 sayııı Orman Kanunu'nun yürürlükten kaldırdığı 8.2.1937 tarihli ve 3116 sayılı Orman Kanunu ile başlatılmıştı. Bu Kanun ile ormanların tahdidinin beş yıl içinde, orman kadastrosuna esas teşkil edecek orman haritalarının ise on yıl içinde bitirilmesi öngörülmüşse de, ormanların kadastroları tamamlanarak tapu kütüğüne tescilleri yapılamamıştır.|3.7.1945 Tarihinde yürürlüğe giren 4785 sayılı Orman Kanununa Bazı Hükümler Eklenmesine Ve Bu Kanunun Birinci Maddesinde Değişiklik Yapılmasına Dair Kanunun birinci maddesi ile istisnalar dışında gerçek ve tüzel kişilere ait tüm ormanlar devletleştirilmiştir.
24.3.1950 tarihli 5653 sayılı Kanunla orman kadastrosuna esas teşkil edecek orman haritalarının tamamlanmasına ilişkin on yıllık süre "en kısa süre" olarak değiştirilmiş, kamuoyundaki tepkiler üzerine devletleştirilen ormanlardan bir kısmı 24.3.1950 tarihli ve 5658 sayılı Kanunla eski maliklerine iade edilmiştir (Karaca, 20I2).

Bu çalı̧̧aların ardından mevzuattaki ilk düzenlemeler, 1961 Anayasasında görülmektedir. 196I Anayasası'nın 13 I inci maddesi 1970 yılında 1255 sayılı Türkiye Cumhuriyeti Anayasası'nın I 3 I inci Maddesinin Değiştirilmesine Dair Kanun ile değiştirilmiş,' buna dayanılarak 20.06.1973 tarihinde 1744 sayılı 683 I Sayılı Orman Kanununun Bazı Maddelerinin Değiştirilmesine ve Bu Kanuna 3 Ek Madde ile bir Geçici Madde Eklenmesine Dair Kanun ${ }^{2}$ ile 683। sayılı Orman Kanunu'nun 2. maddesi değiştirilerek 2/B uygulamalarının önü açılmıştır (Erdönmez ve diğ. 2010). 1744 sayılı Kanun ile 15.10.196I tarihinden önce bilim ve fen bakımından orman niteliğini tam olarak kaybetmiş olan tarla, bağ, meyvelik, zeytinlik gibi çeşitli tarım alanları ve yerleşim yerleri ile orman olarak muhafazasında bilim ve fen bakımından hiçbir yarar görülmeyen yerlerin orman sınırları dışına çıkarılması hükmü getirilmiştir. ${ }^{3}$ Bu düzenlemelere dayanarak, orman mevzuatı içinde 2. Madde uygulamasına yönelik çalışmalar 1974 yılında başlamıştır.

1980 sonrası dönemde neoliberal politikaların, kapitalist üretimin ve bu üretimin mülkiyet ile kurduğu ilişkilerin bir uzantısı olarak Türkiye'de kısaca 2/B sorunu olarak adlandırılan ${ }^{4}$ bir süreç kentleri tehdit etmeye başlamıştır. Bu süreç içinde, orman arazileri içinde yer alan mülkiyetlerde, belirgin biçimde artan oranda bir el değiştirme süreci baş göstermiştir. Orman

196I Anayasası'nın 131. Maddesi şöyledir”: Devlet, ormanların korunması ve ormanlık sahaların genişletilmesi için gerekli kanunları koyar ve tedbirleri alır. Bütün ormanların gözetimi Devlete aittir. Devlet ormanları, kanuna göre Devletçe yönetilir ve işletilir. Devlet ormanlarının mülkiyeti, yönetimi ve işletilmesi özel kişilere devrolunamaz. Bu ormanlar, zaman așımıyla mülk edinilemez ve kamu yararı dışında irtifak hakkına konu olamaz. Ormanlara zarar verebilecek hiçbir faaliyet ve eyleme müsaade edilemez. Ormanlar içinde veya hemen yakınında oturan halkın kalkındıııması ve ormanı koruma bakımından, gerekirse başka yere yerleştirilmesi kanunla düzenlenir. Yanan ormanların yerinde yeni orman yetiştirilir ve bu yerlerde başka çeşit tarım ve hayvancılık yapılamaz. Orman suçları için genel af çıkarılmaz; ormanların tahribine yol açacak hiçbir siyasî propaganda yapılamaz". Söz konusu Madde, 17.4.1970 tarih ve I255 sayılı Kanunla aşağıdaki şekilde değiştirilmiştir:

“c) Ormanların ve Orman Köylüsünün Korunması, Ormanların Geliştirilmesi

“MADDE |3।.- Devlet, ormanların korunması ve ormanlık sahaların genişletilmesi ve gerekli kanunları koyar ve tedbirleri alır. Bütün ormanların gözetimi Devlete aittir. Devlet ormanları, kanuna göre Devletçe yönetilir ve işletilir. Devlet ormanlarının mülkiyeti, yönetimi ve işletilmesi özel kişilere devrolunamaz. Bu ormanlar, zaman aşımıyla mülk edinilemez ve kamu yararı dışında irtifak hakkına konu olamaz. Ormanlara zarar verebilecek hiçbir faaliyet ve eyleme müsaade edilemez. Ormanlar içinde veya hemen yakınında oturan halkın kalkındırılması ve ormanı koruma bakımından, ormanın gözetilmesinde ve işletilmesinde Devletle bu halkın işbirliği yapmasını sağlayıc tedbirler ve gereken hallerde başka yere yerleştirme kanunla düzenlenir. Anayasa'nın yürürlüğe girdiği tarihten önce bilim ve fen bakımından orman niteliğini tam olarak kaybetmiş olan tarla, bağ, meyvelik, zeytinlik gibi çeşitli tarım alanlarında veya hayvancılıkta kullanılmasında yarar bulunan topraklarla şehir, kasaba ve köy yapılarının toplu olarak bulunduğu yerler dışında orman sınırlarında hiçbir daraltma yapılamaz. Yanan ormanların yerinde yeni orman yetiştirilir ve bu yerlerde başka çeşit tarım ve hayvancılık yapılamaz. Ormanların tahrip edilmesine yol açan hiçbir siyasî propaganda yapılamaz".

2 04.07.1973 tarih ve 14584 sayılı RG.

3 Atbaşoğlu (2003)'na göre, ormanlarda nitelik kaybı, yalnızca şu nedenlerle olabilmektedir:

-Büyük bir deprem felaketi yüzünden orman alanlarının altüst olması ve bunun bir sonucu olarak, orman alanlarında bir daha ağaç ve bitki yetişmeyecek kaya veya benzer örtünün gelmesi,

•Küresel ısınma gibi büyük bir felaket sonucu, orman alanlarının erozyona uğrayarak çölleşmesi,

- Bir göktaşı düşmesi sonucu orman alanlarının tahrip olması ve bir daha ağaç ve bitki yetişmesi olanaklarının tümden kaybolması

4 2/B ifadesi 683I sayılı Orman Kanunu'nun 2. maddesinin b fıkrasından kaynaklanmaktadır. Aslında 2. maddenin a fıkrası da aynı şekilde konuyla doğrudan ilişkilidir. Bununla birlikte konu, kamuoyu önünde 2/B olarak bilinmektedir.

Madde 2 (Değişik : 5/6/1986 - 3302/I md.))

Orman sayılan yerlerden;

A) Öncelikle oran içindeki köyler halkının kısmen veya tamamen yerleştirilmesi maksadıyla, orman olarak muhafazasında bilim ve fen bakımından hiçbir yarar görülmeyen aksine tarım alanlarına dönüştürülmesinde yarar olduğu tespit edilen yerler ile halen orman rejimi içinde bulunan funda ve makilerle örtülü yerlerden tarım alanlarına dönüştürülmesinde yarar olduğu tespit edilen yerler,

B) $31 /$ I2/I98। tarihinden önce bilim ve fen bakımından orman niteliğini tam olarak kaybetmiş yerlerden; tarla, bağ, bahçe, meyvelik, zeytinlik, fındıklık, fıstıklık (antep fıstığı, çam fıstığı gibi) çeşitli tarım alanları veya otlak, kışlak, yaylak gibi hayvancılıkta kullanılmasında yarar olduğu tespit edilen araziler ile şehir, kasaba ve köy yapılarını toplu olarak bulunduğu yerleşim alanları. 
kadastrosu işlemleri hemen hemen tamamlanmış, bir taraftan da orman vasfını kaybetmeleri nedeniyle mülkiyeti Hazineye ait olmak koşuluyla orman sınırı dışına çıkarılan arazilerin satışına yönelik girişimler ivme kazanmıştır. Gülöksüz (20l0), bu gelişmelerin ardında, sınıflararası ilişkilerdeki dönüşümlerin şekillendirdiği devletin biçim ve işlevlerindeki dönüşümün yattığını vurgulamaktadır. Çağlar (20I5)'a göre, ormancılık ülkemizde siyasal etkileri olan ve bunun yanı sıra siyasal kararlardan etkilenen bir çalışma konusudur. Nitekim 1980 sonrası dönemde devletin yeni rolü içinde belki de en çarpıcı dönüşümün sermaye ve siyaset ilişkisi çerçevesinde yaşandığı ve bu yeni rolün tüm kent mekanında olduğu gibi, kentsel rant açısından önemli bir değere sahip olan orman vasfını kaybetmiş alanlarda da giderek daha belirgin hale geldiği düşünülürse, bu tespitin son derece yerinde olduğu görülecektir. Atmış ve Günşen (2016), siyasi partilerin orman politikası konusunda yaptıkları araştırmada, 2/B konusunun diğer konulara göre partilerin gündeminde daha çok yer işgal ettiğini vurgulamış, ancak geliştirilen politikaların kamu yararı içeriğine sahip olmadığını ortaya koymuşlardır. Böylece orman alanlarının, özellikle de 2/B alanlarının kentsel rantın konusu olduğuna bir kez daha dikkat çekmişlerdir.

Giriş ve sonuç bölümlerinin dışında, beş temel bölümden oluşan bu çalışma, Gülöksüz'ün sözünü ettiği üçüncü dönüm noktası olan 1980 sonrası döneme yoğunlaşarak, ancak zaman zaman geriye doğru da giderek, orman sınırı dışına çıkartılmış alanlar sorununa yaklaşmayı hedeflemektedir.

İlk bölümde bir kamu malı olarak orman kavramı ele alınıp incelenmiş, ikinci bölümde orman sınırı dışına çıkartılmış alanlarda yer alan sorunlar tarif edilmiştir. Üçüncü bölümde orman sınırı dışına çıkarma işleminin yasal gelişim süreci kronolojik olarak aktarılmış, dördüncü bölümde orman sınırları dışına çıkartılmış alanlarda planlama sorunu, söz konusu sorunun mekanda en fazla kendini göstermekte olduğu, sermaye birikim süreçlerinin mekana en fazla baskıda bulunduğu İstanbul özelinde irdelenmiş ve son olarak beşinci bölümde orman sınırı dışına çıkartılmış alanlar için bir yaklaşım önerisi geliştirilmiştir.

\section{Kamu Malı Olarak Orman}

Devlet ormanları, kamu malları arasında yer alan doğal varIıklarıdır. Ormancılık faaliyetleri ülkemizde mevzuata konu olduğu ilk zamanlardan bu yana kamu hizmeti olarak kabul görmüştür. Ormanların yasal durumları, Anayasa'da ve yasalarda da yer bulmuştur. 1982 Tarihli T.C. Anayasası, devlet ormanlarının mülkiyetinin devredilemeyeceği, zaman aşımı yoluyla mülk edinilemeyeceği ve kamu yararı dışında irtifak hakkına konu edinilemeyeceğini tartışmaya yer bırakmayacak şekilde ortaya koymaktadır. Nitekim 3402 sayılı Kadastro Kanunu da bir yandan ormanları devletin hüküm ve tasarrufu altındaki yerler arasında tanımlarken, bir yandan da ormanların zaman aşımı yoluyla iktisap edilemeyeceğini açıkça belirtir. ${ }^{5}$

Konuya kamu malları üzerinde devletin sahip olduğu hakkın hukuki niteliği perspektifinden yaklaşan Ayanoğlu (1985), devletin ormanlar üzerindeki tasarruf hakkını tartışan görüşleri sıraladıktan sonra, ormanın bir kamu malı olduğu savını destekler. Bu savı destekleyen ilk yasal düzenlemelerden biri, henüzCumhuriyetin kuruluş dönemlerine rastlayan 1924 tarihli ve 504 sayılı yasadır. Söz konusu yasaya göre, "Ormanlar kimin mülkiyetinde bulunursa bulunsun, milletin müşterek malıdır. Milletçe kalkınma ve refah kaynaklarının da en önemlisidir. Varlıklarının emniyet altına alınması ve bunlardan yapılacak faydalanmanın nizamlanması için Devletin politik ve teknik murakabe ve garantisi altında bulunmaları gerekir".

Görüldüğü üzere, kamu malı olarak ormanların devlet güvencesi altında ve bir bütün olarak korunması en temel ilke olarak kabul edilmek durumundadır. Buna karşılık, uygulamada çok sık karşılaşılan Anayasa ve yasaların da olanak tanıması ile, bir yandan orman sınırı dışına çıkartılan alanlar, diğer tarafından başta vakıf üniversiteleri olmak üzere çeşitli kurumlara "kamu yararı" ya da "üstün kamu yararı" gerekçesi ile tahsis edilen, kiralanan alanlar, bu temel ilkenin kökten sarsılmasına yol açmaktadır.

Bunun bir örneğini orman arazisi içine inşa edilen Koç Üniversitesi davasında görmek mümkündür:

Orman Yasası'nda, 1987 yılında yapılan bir değişiklikle, "her türlü bina ve tesisler için” bedel karşılığında ve kırkdokuz yıla kadar izin verilmesi mümkün kılınmıştır. İstanbul'da Mavromoloz Devlet Ormanı içinde bir özel üniversitenin inşa edilmesi üzerine açılan davada, Anayasa Mahkemesi, "her türlü bina ve tesisler için" deyimine sınırlama getirmiş, yalnızca irtifak hakkı tesis edilmesiyle söz konusu bina ve tesislerin yapılabileceğini öngörmüş, verilecek izinlerin "kamu yararının bulunması ve zorunluluk hallerinde” olanaklı olduğunu açıklayarak Orman Yasası'nın 17. maddesini iptal etmiştir (Anayasa Mahkemesinin 17.I2.2002 tarihli ve Esas No: 2000/75, Karar No: 2002/200 sayılı kararı).

Bunun üzerine, Orman Yasası'nın 17. maddesinde, ormanlarda özel üniversite yapımını da hukukileştirecek şekilde, 2004 tarihli ve 5192 sayılı Yasa ile değişiklik yapılmıştır. Yapılan değişiklikle, ormanlarda inşa edilecek bina ve tesislerin sayısı artırılmış ve ayrıca bu bina ve tesisler tek tek sayılmıştır. Buna göre, ormanlarda, savunma, ulaşım, enerji, haberleşme, su, atık su, petrol, doğalgaz, altyapı ve katı atık bertaraf tesislerinin; sanatoryum, baraj, gölet ve mezarlıkların; Devlete ait sağlık, eğitim ve spor tesislerinin ve bunlarla ilgili her türlü yer ve binanın "kamu yararı ve zaruret olması halinde", gerçek ve

\footnotetext{
5 Bkz. 3402 sayılı Kadastro Kanunu'nun 16 ve 18. maddeleri.
} 
tüzel kişilere bedeli karşılığında Çevre ve Orman Bakanlığınca izin verilebileceği kabul edilmiştir. İzin süresinin kırkdokuz yılı geçemeyeceği, ancak bazı şartların gerçekleşmesi halinde bu sürenin doksandokuz yıla kadar uzatılabileceği belirtilmiştir.

Söz konusu olayda, Sarıyer, Rumelifeneri Köyü Mevkiindeki Mavromoloz Devlet Ormanı içinde kalan 160 hektarlık arazi, Özel Üniversite Kampüsü kurulmak üzere, Bakanlar Kurulu'nun 26.04.1992 tarihli kararı ile 49 yıllı̆̆ına Koç Üniversitesi'ne tahsis edilmiştir. Bayındırlık ve İskan Bakanlığı 27.0I.1998 tarihinde onaylanan I/50.000 ölçekli Metropoliten İmar Planı ile Sarıyer, Rumelifeneri Mevkiindeki Mavromoloz Devlet Ormanı içinde bulunan alanı "Üniversite Alanı" olarak belirlenmiştir. Aynı alan, Bayındırlık ve İskan Bakanlı̆̆ınca I 5. I I. I 995 tarihinde onanan I/50 000 ölçekli İstanbul Metropoliten Alan İmar Planı'nda kısmen bölge parkı ve orman alanı olarak nitelendirilmiştir. Söz konusu alan aynı zamanda İstanbul 3 no'lu Kültür ve Tabiat Varlıklarını Koruma Kurulu'nun I5. I I.|995 tarihli kararıyla Doğal Sit alanıdır. İstanbul Büyükşehir Belediyesi, yürürlükte olan planın "planlama genel ilkelerini, stratejilerini, hedeflerini ve üniversite alanı için getirdiği düzenlemeleri bozduğu, büyükşehir belediyesinin görüşünün alınmadığı ve yeşil alan miktarının azaltıldığı"gibi gerekçelerle Bakanlıkça yapılan İstanbul Metropoliten Alan İmar Planı'nın iptali için dava açmıştır. Konuya ilişkin Bilirkişi raporunda; "bu alanda 3 bölgede üniversite alanı ayrıldığı, yörenin güney, batı ve doğusunda yoğun orman dokusunun bulunduğu, onama sınırı içinde bulunan 426 sayılı parselin ormanda açılmış bir alan olduğu, üniversite kararı başka işlevleri de çekeceğinden, Büyük Barajı'nın uzun mesafeli koruma alanında olması nedeniyle baraj suyunun kirlenmeden korunmasının yanı sıra, yakın çevredeki orman alanlarının korunmasını da tehlikeye atacak nitelikte olduğu, üniversite alanının, plan stratejilerini, dolayısıyla Nazım Plan kararlarını bozucu nitelik taşıdığı" belirtilmiştir. Danıştay kararında orman alanlarının korunması ve geliştirilmesi sırasında ormanın korunması faaliyetinin kalkınma çabalarına olumlu ve olumsuz etkileri ile fayda ve sakıncaları dikkate almak, kısa ve uzun vadeli değerlendirmeler yapmak ve bu şekilde kamu yararı açısından dengeyi kurmak gerektiğini vurgulamıştır. Danıştay, Koç Üniversitesi kararında imar planlarının hukuka uygunluğuna ilişkin yerleşik içtihadında yer alan kriterleri genişletmiş ve imar planlarının hukuka uygun olarak nitelendirilebilmesi için üstün kamu yararı ilkesinin gözetilmesi gerektiği sonucuna varmıştır. Bu kapsamda Danıştay 6. Dairesi, “İmar planlarının yargısal denetimi sırasında şehircilik ilkeleri, planlama esasları ve kamu yararı kriterleri ile birlikte özelliği itibariyle imar planının bütünlüğü, genel yapısı, kapsadığı alanın nitelikleri ve çevrenin korunması gibi olguların yanı sıra "üstün kamu yararı" ilkesinin de gözetilmesi zorunludur." şeklinde karar vermiştir (Ovalıoğlu, 20 I5). I3.09.2000 gün ve 2000/2I sayılı Anayasa Mahkemesi kararı ile orman alanlarının vakıf üniversitelerine tahsisinin, ormanların korunması ve bütünlüğünün bozulmaması ilkesiyle bağdaşmadığı gibi, kamu yararının zorunlu kıldığı durumlar arasında da kabul edilemeyeceği karara bağlanmıştır. Bu kararla, 28.12.1999 günlü 4498 sayılı Yükseköğrenim Kanunu'nda Değişiklik Yapılmasına Dair Kanun'un orman alanlarının vakıf üniversitelerine tahsisine ilişkin kısmı iptal edilmiştir. Anayasa Mahkemesinin bu iptal kararı üzerine Danıştay alanın 49 yıllığına Koç Üniversitesine verilmesine ilişkin izin ve tahsis işlemlerini iptal etmiş, davayı devlet kazanmış olsa da, düzenlenen bir protokolle Koç Üniversitesi alanı kiralamıştır. Alana üniversite kurulması amacıyla bedelli izin verilmesine ilişkin işlemin iptali istemiyle Orman Bakanlığı'na karşı açılan davada, İstanbul 2 no'lu Mahkeme, itiraz konusu kuralın Anayasa'ya aykırı olduğu kanısına vararak iptali için başvurmuştur. Bu başvuruya istinaden alınan Anayasa Mahkemesinin I7.I2.2002 tarih ve E.2000/75, K.2002/200 sayılı Kararında “...kamu yararının bulunması ve zorunluluk hallerinde Devlet ormanları üzerinde ancak irtifak hakkı tesisine olanak tanınabilir" denilmiştir. 19 Ocak 2008 tarihli, E: 2004/67Ka: 2007/83 sayılı bir başka Anayasa Mahkemesi Kararında, bu karara atıf yapılarak, "Burada kastedilen koşul, izin konularının sayılması olmayıp; orman ekosisteminde gerçekleştirilmek istenilen etkinliğin daha büyük kamu yararı yarattığının ortaya konulmasıdır" denilmiş ve "Iptali istenen hükümlerde belirtilen zaruret halini, talep edilen faaliyetin orman ekosistemi dışında gerçekleştirilmesi imkanı bulunmaması durumu olarak anlamak gerekir" ifadesine yer verilmiştir.

Şimşek (2010), ormanların kamu malı olması nedeniyle arazi kadastrosu esnasında şahıslar adına tescil edilen ormanların tapularının, Kadastro Kanunu'nun 12. Maddesinde yer alan 10 yıllık hak düşürücü süre geçmiş olsa bile, açılan davalar ya da kadastro uygulamaları neticesinde iptal edildiğini ve bunların Hazine adına tescil edildiğini belirtmekte ve bu konudaki Yargıtay kararlarına dikkat çekmekte; Yargıtayın istikrar kazanmış kararlarında 10 yıllık hak düşürücü sürenin kamu malı niteliğinde olan ormanlar açısından geçerli olamayacağı, bu taşınmazlar için her zaman tapu iptali davası açılmasının mümkün olduğunun vurgulandığını belirtmektedir. ${ }^{6}$

\section{Orman Sınırı Dışına Çıkartılmış Alanlar Sorunu}

Orman, yapılan tanımlamalara göre yalıızca ağaç topluluklarından ibaret bir alan değildir. 683I sayılı Orman Kanunu'nun I. maddesi, ormanı yalnızca ağaç ve ağaççık topluluğu olarak değil, yerleri ile birlikte ele almaktadır. Keleş ve diğ. (2009), orman ekosisteminin bileşenleri olarak üç başlıktan söz ederler. Bunlar;

6 08.05.1987 tarihli ve E:1987/3, K:1987/4 sayılı Yargıtay İçtihadı Birleştirme kararından (aktaran. Şimşek S., 20I0): "Gerçekten Yargıtay’da yerleşmiş ve kararılık kazanmış uygulamaya göre 35. maddede yer alan taşınmazların kişi adına tespit ve tescili halinde bu tescil aleyhine açılacak dava 3 I. maddedeki süreye tabi değildir. ... Eșitlik ilkesi aynı durum ve koşullar altında bulunanların aynı uygulamaya tabi tutulmaların ifade eder. Kamu tașınmazları herhangi bir nedenle zuhulen tescil edilse dahi hukuksal mahiyet ve niteliklerin kaybetmezler; yasa koyucu bu nedenlerle de 35. maddedeki sınırlandırmanın tescil mahiyetinde olmadığıı hükme bağlamıştır. Bu yolda açılacak davanın dayanağını özel hukuk hükümleri oluşturmaz." 
Tablo I. Farklı kullanımlara göre 2/B alanlarının sınıflandırılması

\begin{tabular}{llcc}
\hline Amacı & Yerleşim durumu & Yasal durumu & Müdahale durumu \\
\hline Konut & Orman bütünlüğünü bozan 2/B alanları & Plan kararı ile & \\
& Mevcut yerleşimle bütünleşmiş 2/B alanları & Plan kararı olmadan & Yıkarak ormana kazandırma \\
Eğitim & Orman bütünlüğünü bozan 2/B alanları & Plan kararı ile & Rehabilitasyon \\
& Mevcut yerleşimle bütünleşmiş 2/B alanları & Plan kararı olmadan & Kentsel dönüşüm \\
Tarım & Amacı ve kullanım türüne göre ayrılmış 2/B alanları & Plan kararı ile & \\
Sanayi & Amacı ve kullanım türüne göre ayrılmış 2/B alanları & Plan kararı olmadan &
\end{tabular}

- Ağaç topluluğu

- Memelilerden mikroskopla görülebilecek hayvansal canlılara kadar uzanan hayvan toplulukları ve çalılardan bakterilere değin giden bitki örtüsü

- Toprak ve iklim koşulları olarak kümelenmektedirler.

Özetle, orman denildiğinde içinde çok sayıda bileşenin bulunduğu bir ekosistem bütününden söz edilmektedir. Ancak, 683I sayılı Orman Kanunu'nun "2/B" maddesinde, I. maddenin tam aksi bir şekilde bu yaklaşımın tersine, ormana yalnızca ağaç ve ağaç̧̧ı topluluğu olarak yaklaşılmaktadır.

Ülkemiz ormanlarının en temel sorunu olan ormansızlaşma, ormanı oluşturan öğelerin bir kısmının ya da tümünün ortadan kalkması suretiyle, ormanın kendini yenileyebilir bir ekosistem olma özelliğini yitirmesi olarak tanımlanır (Keleş ve diğ., 2009). Bu durum aslında orman vasfını kaybetmiş alanlar sorununun en can alıı noktasını oluşturmaktadır. Sorun yalnızca yapılaşmaya bağlı bir yeşil alan kaybı sorunu değildir. Bu alanların orman sınırı dışına çıkartııı yapılaşmaya açıımasıyla tüm ekosistem tahribata uğramaktadır.

Orman ve Su İşleri Bakanlığı'nın 2010 yılı istatistik verilerine göre, ülkemiz yüzölçümünün 21.537 .09 l hektarı, yani yaklaşık \%26'sı orman alanıdır (http://web.ogm.gov.tr/ Dkmanlar/istatistikler/ormancilik_ist_20l0.pdf). Bunun $4.374,19$ km²'si, yani yaklaşık \%2,3'ünü orman sınırı dışına çıkartılmış alanlar oluşturmaktadır. 2/B alanları üzerindeki yerleşim yeri olarak tespit edilen alan ise 21.173 hektardir (Tablo I, 2).

Sorunun teknik boyutu olduğu kadar, bir ekonomik boyutuda olduğu açıkça ortadadır. Bu durum, TMMOB(2006) tarafından şöyle ortaya konulmaktadır: "2/B sorununun özü şudur: Orman sınırları dışına çıkarılan yerlerin "rayiç değer"den satılarak, yaklaşık 4.5 milyar $\mathrm{m}^{2}$ 'lik alanı kapsayan "2/B" arazilerinin başka hiçbir kaygı duyulmadan, yalnızca, serbest piyasaya dayalı "küresel pazar ekonomisi"nde alını satılabilir bir meta olarak değerlendirilmesidir".
Tablo 2. Ülkemizde 2/B alanlarının mevcut kullanımları

\begin{tabular}{lcc}
\hline Kullanım şekli & Miktar (ha) & Oran (\%) \\
\hline Köy yerleşim alanı & 7.035 & 1.7 \\
Belde yerleşim alanı & 8.514 & 2 \\
İlçe yerleşim alanı & 6.624 & 1.6 \\
Sera alanı & 2.365 & 0.6 \\
Narenciye alanı & 8.041 & 1.9 \\
Zeytinlik, fıstıklık, bağ, bahçe & 111.115 & 27 \\
Otlak, yaylak, kışlak & 35.419 & 8.6 \\
Diğer ekili alanlar & 230.887 & 56.3 \\
Toplam (yaklaşık) & 410.000 & 100 \\
\hline
\end{tabular}

Kaynak: http://milliemlak.gov.tr/web/guest/istatistiksel-bilgiler

Orman içindeki değerli arazilerin orman sınırı dışına çıkartılması, bu alanlara herhangi boş bir arazi gibi yaklaşıldığının açık göstergesidir.

\section{Orman Sınııı Dışına Çıkarma İşleminin Yasal Gelişim Süreci}

Orman alanlarını orman sınırları dışına çıkartma ve özel orman alanları yaratma sürecinin 1920 yılında 39 sayılı Baltalık Yasası ile başlamış olduğu söylenebilir. Bu yasa ile savaş alanı halindeki Anadolu'nun yoksul köylüsüne hane başına 20 dönüm orman alanı verilmesi sağlanmıştır (Acun, 1998). Ancak bu uygulamanın olumsuz sonuçlarının farkedilmesi üzerine, uygulamadan hızla vazgeçilmiş ve 1924 yılında 504 sayılı yasa ile ormanlar milli servet olarak devlet güvencesi altına alınmıştır. Bu uygulamanın bir devamı olarak, 1945 yııında çıkan 4785 sayılı, 3 I I 6 sayılı Orman Kanunu'na Bazı Hükümler Eklenmesine ve Bu Kanunun I. Maddesinde Değişiklik Yapılması Hakkında Kanun ile özel ormanların devletleştirilmesi sağlanmış ve böylelikle 1937 yılında ülke ormanlarının \%92'si devlet elindeyken bu oranın daha da artırılması hedeflenmiştir.

1950 yılında yürürlüğe giren 5653 sayılı Orman Kanununun Bazı Maddelerinin Değiştirilmesine ve Bu Kanuna Bazı Mad- 
deler Eklenmesine Dair Kanun ile 3116 veya 4785 sayılı Kanunların yürürlüğe girdiği tarihte orman olup da 03.04.1950 tarihine kadar bu niteliğini kaybetmiş olan yerlerin orman sayılmayacağı karara bağlanmış, bu yerlerden tapusuz olanların ise zaman aşımı yoluyla kazanılabileceği, tapulu olanları ise özel orman sayılacağı belirtilmiştir.

Özel ormanların yönetimi ve muhafazası, Devletin kontrol ve denetimi altında olmak üzere 31.08.1956 tarihli ve 683 I sayılı Orman Yasası'nın 55. maddesi hükümlerine göre maliklerine ait olmakla beraber, imar ve planlama faaliyetleri Orman Yasası'nın 52. maddesinde ayrıntılı bir şekilde tanımlanmıştır.

Buna göre, özel ormanlarda;

I. Çevre ve Şehircilik Bakanlığı'ndan izin almak,

2. Parselin tapuda kayıtlı yatay alanının yüzde altısını (\%6) geçmemek,

3. İmar planlamasına uygun olmak,

koşulları ile inşaat yapılabilecektir.

683 I sayılı Orman Yasası'nın 50, 5I, 52, 53, 54, 55 ve 56. maddeleri ile düzenlenen özel ormanlarda inşaat yapılması hakkındaki kurallar, 25 Nisan 2002 tarihli (Değişiklik: 26.07.2005) Resmi Gazete'de yayımlanan, "Özel Ormanlarda ve Hükmi Şahsiyeti Haiz Amme Müesseselerine Ait Ormanlarda Yapılacak İş ve İşlemler Hakkında Yönetmelik” ile düzenlenmiştir.

31.08.1956 tarihinde 683I sayılı Orman Kanunu yürürlüğe girmiştir. Söz konusu kanun, orman vasfını kaybeden alanların orman sınırı dışına çıkartılmasını düzenlemiştir. (Anbar, 2004) burada temelde iki amaç bulunduğundan sözetmektedir. Birinci amaç; gerçekte orman olmadığı halde hatalı olarak orman sınırları içine alınmış ve itirazsız olarak kesinleşmiş yerlerin orman sınırları dışına çıkartılmasıdır.

İkinci amaç ise; 3116 sayılı yasaya göre sadece devlet ormanlarının sınırlandırılmış olması, oysa 4785 sayılı yasa ile bütün orman alanlarının devletleştirilmiş olması ve işte bu bu tip yerlerin nitelik kaybından dolayı orman sınırları dışına çıkartılmasıdır. 4785 sayılı yasa ile Devlet ormanları içinde olmayan ve etrafı tarla, bağ, bahçe gibi kültür arazisi, özel orman, şehir, kasaba, köy merası ve Orman Kanunun birinci maddesine göre orman sayılmayan yerlerle çevrili olmak şartiyle Devlet ormanlarından tamamen ayrılmış bulunan köy, belediye tüzelkişiliklerine ve gerçek kişilere ait ormanlar; sahipleri veya mirasçıları istedikleri takdirde geri verilmektedir.

Ormanla ilgili politikalara daha sonra 196I Anayasası'nda rastlanmaktadır. Anayasa ile, "kamu yararı"nı esas alan korumacı bir yaklaşım benimsenmiş ve devlet ormanlarının Devletçe yönetilip işletileceği, bu ormanların mülkiyeti, yönetimi ve işletil- mesinin özel kişilere devrolunamayacağı, zamanaşımıyla mülk edinilemeyecekleri ve kamu yararı dışında irtifak hakkına konu olamayacakları açıkça belirtilmiştir.?

1970 yılından itibaren, 1961 Anayasası'nın benimsediği bu korumacı tutum yön değiştirmiş ve orman sınırlarında daraltma konusu Anayasa'nın 131. maddesinde değişiklik yapan 1255 sayılı Yasa ve bunun hemen ardından da 20.6.1973 tarihli, I744 sayılı Yasa ile gündeme gelmiştir. Böylece, I255 sayılı Yasa ile "Anayasa'nın yürürlüğe girdiği tarihten önce bilim ve fen bakımından orman niteliğini tam olarak kaybetmiş olan tarla, bağ, meyvelik, zeytinlik gibi çeşitli tarım alanlarında veya hayvancılıkta kullanılmasında yarar bulunan topraklarla; şehir, kasaba ve köy yapılarının toplu olarak bulunduğu yerler dışında orman sınırlarında hiçbir daraltma yapılamaz" ifadesiyle, orman sınırları dışına çıkartılma işlemleri hayata geçirilmiştir. I744 sayılı Yasa'nın 2. maddesinde ise, benzer şekilde,"I5.10.196I gününden önce bilim ve fen bakımından orman niteliğini tam olarak kaybetmiş yerlerden; a) Su ve toprak rejimine zarar vermeyen, orman bütünlüğünü bozmayan tarla, bağ, meyvelik, zeytinlik, findıklık, fistıklık (antepfıstığı) gibi çeşitli tarım alanlarında ve hayvancılıkta kullanılmasında yarar bulunan yerler ile otlak, kışlak ve yaylak haline gelmiş yerler, b) Şehir, kasaba ve köy yapılarının toplu olarak bulunduğu yerleşim sahaları orman sınırları dışına çıkarılır." ifadeleri yer bulmuş ve orman sınırları dışına çıkartılma işlemleri hızlanmıştır. Yasa, orman sınırı dışına çıkartılma işlemlerinin, yasanın yürürlük tarihi olan 1973 yılından itibaren 10 yıllık süre içinde yapılmasını öngörmektedir.

1980'li yıllara gelindiğinde, orman sınırı dışına çıkartmaya yönelik yasal düzenlemelerin ivme kazanmaya başladığı söylenebilir. 1982 tarihinde yürürlüğe giren yeni Anayasa, bir önceki Anayasa'nın ormanlara yönelik korumacı politikasından vazgeçmiş, orman sınırı dışına çıkartılan yerler konusu, bu dönemin sonrasında büyük bir kaosu da beraberinde getirecek şekilde öne çıkmıştır. "Orman olarak muhafazasında bilim ve fen bakımından hiçbir yarar görülmeyen aksine tarım alanlarına dönüştürülmesinde kesin yarar olduğu tespit edilen yerler ile, 3I.I2.198I tarihinden önce bilim ve fen bakımından orman niteliğini tam olarak kaybetmiş olan tarla, bağ, meyvelik, zeytinlik gibi çeşitli tarım alanlarında veya hayvancılıkta kullanılmasında yarar olduğu tespit edilen araziler, şehir, kasaba ve köy yapılarının toplu olarak bulunduğu yerler dışında orman sınırlarında daraltma yapılamaz." "şeklindeki düzenlemenin ardından gelen yasal düzenlemeler, başta büyük kentler olmak üzere, tüm ülke ormanlarının yapılaşmaya açılmasının zeminini oluşturmuş, böylelikle büyük bir pazar yaratılmıştır.

1983 yılında 2924 sayılı Orman Köylülerinin Kalkınmalarının Desteklenmesi Hakkında Kanun yürürlüğe girmiştir. Söz konusu kanun, 2/A maddesi kapsamındaki alanlar için yapılacak

\footnotetext{
7 196I Anayasası Md. I3I, fikra 2.

81982 Anayasası md. 169., fikra 4.
} 
orman sınırı dışına çıkartma ile ilgili açılacak davaların bu kanuna göre yapılacak işlemleri durdurmayacağını, konuyla ilgili davalarda yürütmeyi durdurma ve ihtiyati tedbir kararı verilemeyeceğini belirtir; Kanuna göre, orman sınırı dışına çıkartılan bu yerlerde hak iddia edenlerin açtıkları davalar sonucu gerçek ve tüzel kişilere ait olduğuna karar verilen taşınmaz mallar, genel hükümlere göre kamulaştırılır. 9

Aynı yıl yürürlüğe giren bir başka kanun, 2896 sayılı 3I.8.1956 Tarihli ve 683। Sayılı Orman Kanununun Bazı Maddelerinin Değiştirilmesine ve Bazı Maddelerinin Yürürlükten Kaldırılmasına illişkin Kanun'dur. Bu kanunla, orman sınırları dışına çıkartma işlemlerinin yürütülmesine ilişkin 1744 sayılı kanunda belirtilen 10 yıllık süre kaldırılmış, sürecin önü sınırsızca açıımışır. Bunun yanı sıra, devlet ormanlarında kamu yararına her türde tesisin yapımına ve 99 yıla kadar kullanımına da izin verilmiştir. ${ }^{10}$

298 I sayılı Kanunun 22.5.1986 gün ve 3290 sayılı "24.2.1984 Tarih ve 298। Sayılı Kanunun Bazı Maddelerinin Değiştirilmesi ve Bu Kanuna Bazı Maddeler Eklenmesi Hakkında Kanun"ile değişik geçici 2. maddesinin (e) bendi uyarınca; 31.12.198। tarihinden önce orman sınırları dışına çıkarılan alanlarda bu Kanun hükümlerine göre işlem yapılacağı hükme bağlanmıştır. Bu hüküm uyarınca, orman sınırları dısına çıkarılan alanların üzerinde bulunan yapılarla birlikte tespit edilerek mülkiyet devri ve bu mülkiyet üzerindeki yapılara yapı ruhsatı ve yapı kullanma izni verilmesi öngörülmüştür. İmar mevzuatına aykırı yapılar imar mevzuatına uygun inşa edilerek yapı kullanma izni alınmış yapılar olarak kabul edilmiştir. Ancak Anayasa Mahkemesinin 27.9.1995 gününde oybirliği ile verdiği ve 28.1 I.2002 tarih ve 24950 sayılı Resmi Gazete'de yayımlanan kararda, 298 I sayılı Kanunun 3290 sayılı Kanun ile değişik 2. maddesi (e) bendi iptal edilmiştir. Anayasanın 169. ve 170. maddelerine aykırı olduğu gerekçeleri ile söz konusu madde iptal edilmiştir.

Yine 1986 yılında 3302 sayılı 31.8.1956 tarihli ve 683I Sayılı Orman Kanununun Bazı Maddelerinin Değiştirilmesine Dair Kanunla, Orman Kanunu'nun 2/A ve 2/B diye bilinen maddeleri yeniden düzenlenmiştir. Söz konusu kanun, özel kişiler adına orman sınırları dışına çıkartma işlemini hangi nedenle olursa olsun reddetmektedir.

1987 yllında yürürlüğe giren 3373 sayılı 683 I Sayılı Orman Kanununun Bazı Maddelerinin Değiştirilmesi ve Bu Kanuna Bazı Hükümler Eklenmesi Hakkında Kanun ile Orman Kanunu'nda değişiklik yapmış ve orman sınırları içinde ve bitişiğinde bulunan tapulu, orman sınırları dışında ise her türlü tasarruf belgeleriyle özel mülkiyette bulunan ve tarım arazisi olarak kullanılan, dağınık veya yer yer küme ve sıra halindeki her nevi ağaç ve ağaçcıklarla örtülü yerler ile orman sınırları dışında olup, yüzölçümü üç hektarı aşmayan sahipli arazideki her nevi ağaç ve ağaçcıklarla örtülü yerlerin orman sayılmayacağı hükme bağlanmışıtır. Aynı Kanun içinde, 52. Madde "Ekim ve dikim suretiyle meydana getirilen hususi ormanlar hariç, hususi ormanlar 500 hektardan küçük parçalar teşkil edecek şekilde parçalanıp başkalarına temlik ve mirascılar arasında ifrazen taksim edilemez. Ancak, şehir, kasaba ve köy yapılarının toplu olarak bulunduğu yerlerdeki hususi orman alanlarında bu Kanunun I7'nci maddesine göre izin almak ve yatay alanın yüzde altısını (\%6) geçmemek üzere imar planlamasına uygun inşaat yapılabilir. İnşaatların yapılmasında orman alanlarının tabii vasıflarının korunmasına özen gösterilir" düzenlemesini getirmiş, böylelikle başta İstanbul ve Boğaziçi olmak üzere birçok toplu yerleşim bölgesinin bulunduğu hususi orman alanı yapılaşmaya açılmıştır.

Anayasa Mahkemesi'nin 1989 yllında "ne olursa olsun orman olarak sınırlandırılmış bir yer, artık ormandır" şeklinde almış olduğu karar," ormanların sınırlarında daraltma yapılamayacağına ve bazı kısımlarııın orman sınırları dışına çıkarılamayacağına açık bir şekilde işaret etmektedir.

1994 tarihli Yargıtay kararı, orman sınırı dışına çıkartılan alanlarda zilyetlik yoluyla toprak kazanma olanağı olmadığını tartışmaya yer bırakmayacak şekilde ortaya koymuştur. ${ }^{12}$

1995 yılında ise, 4I27 sayılı, 2924 Sayılı Orman Köylülerinin Kalkınmalarının Desteklenmesi Hakkında Kanunun Bazı Maddelerinin Değiştirilmesi Hakkında Kanun ile 2924 sayıIı Kanun'da değişiklik yapılmıştır. Bu değişiklikle orman sınırından çıkarılarak tarım alanına dönüştürülen yerlerin satışı konusunda düzenlemeler getirilmiştir. Kanun hükümlerinden yararlanacak kişilerin hak sahibi olabilmesi için, orman köyü nüfusuna kayıtlı olmaları ve bu Kanunun yürürlüğe girdiği tarihten itibaren geriye yönelik en az 5 yıl müddetle o yerde ikamet etmiş bulunmaları gerektiği, 31.12.198। tarihinden itibaren orman köyü nüfusuna kayıtlı olanlar da hak sahibi sayılacakları karara bağlanmış ve rayiç bedelin belirlenerek hak sahiplerine tebliğinden itibaren hak sahiplerince bir yıl içinde satın alınmayan yerlerin, ihale ile hak sahipliği tanımına uygun üçüncü kişilere satılmasının önü açılmıştır.

\footnotetext{
9 Mülga 28/8/1991 - 3763/l md.

102896 sayılı kanun hükmü: Turizm bölge, alan ve merkezleri dışında kalan Devlet ormanlarında; kamu yararına olan her türlü bina ve tesisler ile orman ürünlerini işleyeceklerin yapacakları bina ve tesisler için gerçek ve tüzelkişilere Maliye Bakanlığının görüşü alınarak Tarım ve Orman Bakanlığınca, intifa için kullanım bedeli karşılığında izin verilebilir. Bu izin üzerine tesis edilecek intifa hakkı süresi kırk dokuz yılı geçemez. Bu süre sonunda bütün bina ve tesisler bedelsiz ve eksiksiz olarak Hazineye devredilir. Ancak, işletmelerin başarılı olduğu, konusuyla ilgili bakanlıkça belgelenen hak sahiplerinin intifa hakkı Tarım ve Orman Bakanlığınca; yer, bina ve tesislerin rayiç değeri üzerinden belirlenecek yıllık bedelle doksan dokuz seneye kadar uzatılabilir. Bu durumda Hazineye devir işlemi bu uzatma sonunda yapılır. Bu suretle yapılmasına izin verilen bina ve tesislerin amaç dışı kullanılması yasaktır.

II 14.03.1989, E.1988/35, K.1989/13.

12 7.HD. (1 I.07.1994), E.1994/2796, K.1994/934I

ÖZET: "Öncesi orman iken 683I sayılı Yasanın değişik 2/B maddesi uyarınca nitelik kaybı nedeniyle HAZiNE adına tahdit dışına çıkarılıp, kadastro yolu ile saptanan taşınmazlarda, dışarı çıkarıldığı tarihten sonra dahi olsa zilyetlik yoluyla toprak kazanma olanağı yoktur."
} 
1996 tarihinde orman dışına çıkarılan yerin öncesi orman olduğundan, orman kavramına 'yerlerinin de' dahil olduğu; bitki örtüsünün kaldırılmış olmasının, o yerin orman rejimi dışına kendiliğinden çıkmasını gerektirmeyeceği İçtihadı Birleştirme Büyük Kurulu kararı ile bir kez daha vurgulanmıştır. ${ }^{13}$

02.07.1996 yılında yürürlüğe giren Orman ve Orman Sınırı Dışına Çıkartılan Yerlerin Tescili ${ }^{14}$ konulu genelge, Ormanda veya 683I sayılı Kanun'un 2/B Maddesi Uyarınca Orman Sınırları Dışına Çıkartılan Sahada Kalan Taşınmaz Malların Tasarrufu konusunu orman ve 2/B sınırları içinde kalan alanlar için ayrı ayrı düzenlemiştir. Buna göre,

\section{Orman Alanları İçin:}

- Tamamen orman sınırı içinde kalan tapulu taşınmazların tasarrufu: Kesinleşmiş orman kadastrosu sınırı içinde kalan özel mülkiyet konusu taşınmaz mallarla ilgili talepler Tapu Sicil Müdürlüğü’nce karşılanmaz.

- Kısmen orman sınırı içinde kalan tapulu taşınmazların tasarrufu: Taşınmaz ifraz edilerek orman sınırı içinde kalan kısımla ilgili talepler karşılanmaz.

\section{2/B Alanları İçin:}

- Tamamen 2/B'lik alanda kalan tapulu taşınmazların tasarrufu: Talep konusu taşınmazın 683I sayılı Kanunun 2/B maddesine göre orman sınırı dışına çıkarılan sahada kaldığı hususunda taraflara bilgi verilerek ve bu durum resmi senede yazılarak işlem karşılanır.

13 YARGITAY İçtihadı Birleştirme Büyük Kurulu (23.03.1996), E.1993/5, K.1996/I.

${ }^{14}$ Genelge No: 1996/4 (1532).

15 20.HD. (14.09.1999), E.1999/69/3, K.1999/7075

ÖZET:"Orman olduğu saptanan taşınmazlar üzerinde kişi veya kurumlar lehine sonuç doğurucu muhdesattan söz edilemez."

... Halen eylemli orman olmadığı belirlenerek gerçek kişi adına tescil kararı verilen diğer nizalı yerle ilgili olarak ise, taşınmazın öncesi ve zilyetlikle kazanma koşullarının gerçekleşip gerçekleşmediği yönünden yapılan inceleme ve araştırma hüküm kurmaya yeterli değildir... 3 I I6, 4785, 5658 sayılı Yasalar karşısındaki durumu belirlenmeli, tapu ve zilyetlik yoluyla ormandan yer kazanma olanağının bulunmadığı, üzerindeki orman bitki örtüsü yok edilmiş olsa bile, salt orman toprağııın orman sayılan yer olduğu düşünülmeli, ...uygulama ve araştırmaya dayalı ve tüm bilirkişilerin onayını taşıyan kroki düzenlettirilmeli ve bilimsel rapor alınmalı, ........

Yapılan bu inceleme ve araşıırma sonunda, taşınmazın orman sayılmayan yerlerden bulunduğu saptandı̆̆ı takdirde, tarım bilirkişisi vasıtasıyla; taşınmazın toprak yapısı, bitk örtüsü, komşu hayıtlarda gösteriliş biçimi, ekonomik amacına uygun bir kullanımının var olup olmadığı, zilyetliğin süresi belirlenmeli... ortaya çıkacak sonuca göre bir karar verilmelidir.

16 I7.HD. (30.1 I.1999), E.1999/5287, K.1999/5340

ÖZET: "Orman rejimi dışına çıkarılan taşınmazın kadastro tespiti sırasında, tasarruf eden kişinin beyanlar hanesinde gösterilebilmesi için, öncelikle taşınmazın köy sınırlar içinde olması ve 40//00 dönüm sınırlaması göz önünde bulundurularak, tasarruf eden kişinin orman köyü nüfusuna kayıtlı olup, yasanın yürürlüğe girdiği tarihten geriye doğru en az 5 yıl süre ile o yerde oturmuş olması gerekir."

16. HD. (22.0I.200I), E.2000/5536, K.200I/22

ÖZET:"Orman dı̧̧ına çıkarılan yerlerde zilyedin, kütüğün beyanlar hanesinde gösterilmesi için orman köyü nüfusu kayıtlı olması ve 5 yıl süreyle bu köyde ikamet etmes gerekir. Taşınmazın bulunduğu bölgede belediye teşkilatı bulunduğundan bu olanaklardan yararlanamaz.

Ancak; davacı yararına kazanıımış hak doğup doğmadığııın tespiti için belediyenin kuruluş tarihi araştııılmali; zilyetliğin, kütüğün beyanlar hanesinde gösterilip, gösterilmeyeceği tartışılmalıdır."

${ }_{17}$ Anayasa Mahkemesi Kararı, 30.03.1993, E.1992/48, K.1993/14; Anayasa Mahkemesi Kararı, 27.09.1995, E.1995/13, K.1995/5I; Anayasa Mahkemesi Kararı, 23.01.2002, E.200I/382, K.2002/21

184 Ekim 2002 RG tarihli, 24896 sayılı Anayasa Mahkemesi Kararı (Esas No. 200I/382, Karar No. 2002/2I, Karar Tarihi: 23.I.2002.

19 RG: 15.07.2004.

${ }^{20} 3402$ sayılı Kadastro Kanunu'nun 4. Maddesi uyarınca, kadastro çalışma alanında orman bulunması ve 683I sayılı Orman Kanununa göre orman kadastrosuna başlanılmamış olması halinde, orman kadastrosu ve bu ormanların içinde ve bitişiğinde her çeşit taşınmaz malların ormanlarla müşterek sınırlarının tayini ve tespiti kadastro ekibi tarafindan yapilır. Orman kadastrosu kesinleşmiş yerlerde bu sınırlara aynen uyulur.

Bu yasanın 45. Maddesi ile orman içi yerleşim alanlarının kadastrosunun genel kadastro ekip ve komisyonlarınca yapılacağına dair hükümler konulmuşsa da bu hükümler Anayasa Mahkemesi kararlarıyla iptal edilmiştir. Uygulamada bu hükümlerin de etkili olamaması nedeniyle 4. Madde yeniden değiştirilerek orman iç̧i veya bitişiğinde yapılacak çalışmaların (Bir orman mühendisi ile bir ziraat mühendisinin ekip ve komisyonlara katılması şartı ile) orman kadastrosu sayılması esası kabul edilmiştir.

Orman kadastrosunun tanımı, genel kadastro tanımından ayrı düşünülemez. Bu bağlamda orman kadastrosunu "orman alanlarının geometrik ve hukuki durumlarının tayin ve tespit edilmesi" şeklinde tanımlanabilir. Orman kadastrosunu genel kadastrodan ayıran en önemli özellik orman vasfının tayini işlemidir. Bir yerin orman nitelïginde olup olmadığının tespiti oldukça karmassık ve uzmanlık gerektiren bir isslemdir. Bu nedenle ülkemizde orman kadastrosu issleri genel kadastrodan ayrı tutularak farklı bir komisyon ile çalışmaktadır (Gençay G.Ş., 2009). Bu iki kadastro türünün farklı dönemlerde aynı yer iç̧in yaptıkları sınırlandırmalar arasında uyumsuzluklar ortaya çıkması, birçok sorunu beraberinde getirmiştir. Ancak bu çalışmanın kapsamında olmadığından bu sorunlara burada yer verilmeyecektir (Bu konuda ayrıntılı bir okuma için bkz. Gençay G.Ş., 2009) 
ile 683I sayılı Orman Kanunu'nun değişik 2/B maddesi hükümleri gereğince Hazine adına orman sınırları dışına çıkartılan yerlerin Maliye Bakanlığı uhdesine geçtiği, bu yerlerin satış işlemlerinin yapılabilmesi için yapılacak öncelikli kadastronun Maliye Bakanlığınca yaptırılacağı, imar uygulama ve mevzuatındaki kısıtlamalara tabi olmayacağı, bu yerlerin Harçlar Kanunundaki harca tabi değerinden az olmamak üzere rayiç bedeli üzerinden köylerde, varsa öncelikle kullanıcısı orman köylüsüne, belediye ve mücavir alan sınırları içerisinde ise kullanıcılarına doğrudan satılabileceği gibi aynı amaçla ilgili belediyelere ve Arsa Ofisi Genel Müdürlüğüne devredilebileceğine dair hükümler yer almıştır. Bununla birlikte, 3. Madde hakkında, Kanunun 18.07.200I tarihinde yürürlüğe girmesini takiben, dönemin Cumhurbaşkanınca yürütmenin durdurulması ve iptali talebi ile Anayasa Mahkemesinde açılan davada, mahkeme tarafından verilen ve 15.09.200 I tarih ve 24524 sayılı Resmi Gazete'de yayınlanan 14.09.200 I tarih, 200I/382E, 200I/8 sayılı kararla öncelikle yürütmenin durdurulması kararı verilmiş, ardından 04. 10.2002 tarih ve 24896 sayılı Resmi Gazete'de yayınlanan 23.01.2002 tarih, 200I/382 E., 2002/2I sayılı kararı ile 3. madde tümden iptal edilmiştir. Anayasa Mahkemesi iptal gerekçesinde, "Anayasanın 170. maddesi, orman sınırları dışına çıkartılan yerlerin, ülke nüfusunun dörtte birine yakın bölümünü teşkil eden ve orman içi ve bitişinde yaşayan orman köylüsünün kısmen veya tamamen bu yerlere yerleştirilmesi ve Devlet eliyle anılan yerlerin ihya edilerek ancak bu halkın yararlanmasına tahsis edilmesi gerektiğini Anayasa ile bu işlerin yapılması hususunun Devlete görev olarak yüklenmiş olduğunu, ülke nüfusunun dörtte birine yakın bölümünü teşkil eden, ancak sağlıksız biçimde ve düşük sosyo-ekonomik yapı içinde yaşayan orman içi veya bitişiği köyler halkına, bilim ve fen bakımından orman olarak işletilmesinde hiçbir yarar görülmeyen yerlerin Devlet eliyle ihya edilerek yararlanılmak üzere tahsis edileceği, bu nedenle orman sınırları dışına çıkarılan yerlerin yalnızca orman köyleri halkının nakli ve yerleştirilmesi amacıyla değerlendirilmesinin olanaklı olduğunu, Anayasanın bu emredici kuralı nedeniyle yasa koyucunun, bu alanların kullanıcılarına veya başkalarına, hatta orman içi köyler halkına satılmasını veya bu amaçla devredilmesini sağlayacak bir düzenleme yapmasının mümkün olmadığını, bu nedenle Hazine adına orman sınırları dışına çıkartılan yerlerin satışı ve bu amaçla devrini düzenleyen maddenin Anayasaya aykırı bulunduğunu" belirtmiştir.

Söz konusu yönetmeliğin 16. maddesi, "Orman kadastrosu ve 2/B madde uygulaması yapılacak il ve ilçeler, mülkiyet ihtilaflarının yoğun olduğu yerler ile Devlet yatırım alanlarına, tapu ve kadastro çalışmalarının programa alındığı yerlere öncelik verilerek Genel Müdürlüğün teklifı, Bakanlığın onayı ile belirlenir" düzenlemesi getirmiştir. Yönetmelik, Orman Sınırları Dışına Çıkarılacak ve Çıkarılamayacak Yerleri de 33. madde ile tarif etmiştir. Buna göre, $31 / / 2 / 198 I$ tarihinden önce bilim ve fen bakımından orman niteliğini tam olarak kaybetmiş yerlerden; tarla, bağ, bahçe, meyvelik, zeytinlik, fındıklık, fıstıklık (antep fıstı̆̆ı, çam fıstığı) gibi çeşitli tarım alanları veya otlak, kışlak, yaylak gibi hayvancılıkta kullanılmasında yarar olduğu tespit edilen araziler ile şehir, kasaba ve köy yapılarının toplu olarak bulunduğu yerleşim alanları, Devlet ormanı ise, Hazine adına, hükmî şahsiyeti haiz amme müesseselerine ait orman ise bu müesseseler adına, hususî orman ise sahipleri adına, orman sınırları dışına çıkarılır. Uygulama kesinleştikten sonra sahiplerinin müracaatı üzerine tapuda düzeltme ve tescil işlemleri yapılır... 683I sayılı Kanunun 2/B maddesi hükümleri, muhafaza ormanı, millî park alanları, tabiat parkları, tabiatı koruma alanları ile izin ve irtifak hakkı tesis edilen ormanlık alanlarda ve 683I sayılı Kanunun 3 üncü maddesi ile orman rejimi içine alınan yerlerde bu niteliklerin devamı süresince, yanan orman sahalarında ise hiçbir şekilde uygulanmaz.

I5 Ocak 2009 günü kabul edilen 583 I sayılı "Tapu Kanunu ile Bazı Kanunlarda Değişiklik Yapılmasına Dair Kanun” ile 683I sayılı Orman Yasası'nda ve 3402 sayılı Kadastro Yasası'nda değişiklikler yapılmış, bu değişikliklerle 2/B sorunu bir kez daha kaosa sürüklenmiştir. Kanun'un Orman Yasası'nın 7. ve 9. maddelerinde öngördüğü değişikliklerle, “... henüz orman kadastrosuna başlanılmamış yerlerde," ve "3402 sayılı Kadastro Kanununa göre kadastrosuna başlanan çalışma alanlarında,", Tapu ve Kadastro Genel Müdürlüğü’ne hem orman hem de mülkiyet kadastrosu yapma yetkisi verilmekte ve Tapu ve Kadastro Genel Müdürlüğü eliyle ikinci kadastro adı altında çalışma yapılmasının önü açılmaktadır. Oysaki mevzuata göre bir yerde kadastro tamamlandıktan sonra ikinci bir kadastro yapılması olanaklı değildir. 583I sayılı kanun ile, 3402 sayıIı Kadastro Kanunu'nun, kadastrosu ilan edilerek kesinleşen yerlerde on yıl geçtikten sonra, kadastrodan önceki hukuki sebeplere dayanarak itiraz olunamayacağını ve dava açılamayacağını belirten 12. maddesine bir cümle eklenerek, bu 10 yıllık hak düşürücü sürenin "iddia ve taşınmazın niteliğine yahut Devlet veya diğer kamu tüzel kişileri dahil, tarafların sıfatına bakılmaksızın" tüm taşınmazlar hakkında uygulanacağını hüküm altına almıştır. Yargıtay 20. Hukuk Dairesi'nin 584I sayılı Kanun'la yapılan değişiklikten sonra verdiği kararlarında ${ }^{2 !}$ orman kadastrosu yapılmış bir alanda arazi kadastrosu esnasında şahıslar adına yapılan tespiti ikinci kadastro olarak nitelendirmiş ve bu kadastroların Kadastro Kanunu'nun 22/I. maddesine göre bütün sonuçlarıyla hükümsüz olduğuna, bundan dolayı bu şekilde oluşturulan tapuların hiçbir süreye bağlı olmadan iptal edilebileceğine karar vermiştir. Oysaki Kadastro Kanunu'na eklenen Ek Madde 4 ile 1967 yılında kadastrosu tamamlanmış olan İstanbul'un 2/B alanlarında, yargı kararlarına aykırı olarak

${ }^{21}$ Örnek karar: T.C. Yargıtay 20. Hukuk Dairesi E. 2008/I6930K. 2009/I578T. 5.2.2009- ÖZET: Dava, öncesi orman olan ve kesinleşen orman kadastrosu sınırları içinde kalıp, nitelik kaybı nedeniyle Hazine adına orman rejimi dışına çıkartılan taşınmazın tapu kaydının iptali ve tescil istemine ilişkindir. Dava konusu taşınmaz, kesinleşen orman kadastrosu sınırları içinde olup, daha sonra bilim ve fen bakımından orman niteliğinin kaybı nedeniyle Hazine adına orman dışına çıkarılmıştır. Taşınmaz orman sınırları içinde olduğu halde yapılan arazi kadastrosu ile yolsuz olarak tapu kaydı oluşturulmuş ise de bu ikinci kadastro yolsuz ve geçersiz olduğundan davacıya hiçbir zaman mülkiyet hakkı kazandırmaz. Bu tür kayıtlarda iyiniyetle edinme kuralı da uygulanamaz. 
ve ikinci kadastro" sayılmayarak, sınırlarında her türlü değişiklik ve düzeltmeler yapılabilmesine olanak tanıyacak şekilde yeni bir kadastro sürecinin başlatılmasına zemin hazırlanmıştır.

2/B arazilerinin satışı ile ilgili kısmi bir yasal düzenleme ise, 23.07.2010 tarihinde kabul edilen ve Torba Yasa olan 6009 Sayılı Gelir Vergisi Kanunu İle Bazı Kanun Ve Kanun Hükmünde Kararnamelerde Değişiklik Yapılmasına Dair Kanun ile hayata geçirilmiştir. Bu düzenleme ile, ${ }^{22}$ Hazinenin 2/B arazilerini belediyelere devretmesi, belediyelerin de bu satışı gerçekleştirmesine olanak tanınmıştır.

201 I yılında 644 ve değişik 648 sayılı Kanun Hükmünde Kararname ile Çevre ve Şehircilik Bakanlığı kurulmuştur. Bu Bakanlığın kurulması ile, tabiat varlıkları ile ilgili yetkiler Kültür ve Turizm Bakanlığı'ndan Çevre ve Şehircilik Bakanlığı'na devredilmiştir. Böylece, niteliğinin bozulması nedeniyle orman ve mera dışına çıkarılan alanlar dâhil kentsel ve kırsal alan ve yerleşmelerde yapılacak iyileştirme, yenileme ve dönüşüm uygulamalarında idarelerce uyulacak usul ve esasları belirlemek Çevre ve Şehircilik Bakanlığı'nın görevleri arasına girmiştir. Söz konusu Kararname ile Bakanlık teşkilatı içinde Altyapı ve Kentsel Dönüşüm Hizmetleri Genel Müdürlüğü kurulmuş, vasfının bozulmasından dolayı orman ve mera dışına çıkarılan alanlara ilişkin iyileştirme, yenileme ve dönüşüm uygulamaları yapma görevi bu Müdürlüğe verilmiştir. Bu suretle, 644 ve 648 sayılı Kanun Hükmünde Kararnamelerle, orman sınırı dışına çıkarılan yerlerin dönüştürülerek yapılaşmaya konu olmasının Çevre ve Şehircilik Bakanlığı eliyle gerçekleştirilmesinin önü açılmıştır.

Orman sınırları dışına çıkartılan alanlarla ilgili en yakın gelişmelerden biri de, 20.04.2012 yılında yürürlüğe giren 6292 sayılı "Orman Köylülerinin Kalkınmalarının Desteklenmesi Ve Hazine Adına Orman Sınırları Dışına Çıkarılan Yerlerin Değerlendirilmesi İle Hazineye Ait Tarım Arazilerinin Satışı Hakkında Kanun"dur. Bu Kanunla 4706 sayılı Kanunun 3'üncü maddesinin Anayasa Mahkemesince iptali sonrasında 2/B alanlarının tasarrufuna yönelik hukuki ve idari boşluğun doldurulması hedeflenmiştir. Yasa ile 2/A alanları Orman Genel Müdürlüğü'nün, 2/B alanları ise Maliye Bakanlığı'nın tasarrufuna geçmiş; böylelikle bu alanları tek elden, bütüncül bir yaklaşımla ele alıp politika geliştirme olanağı ortadan kalkmıştır. 2/B alanlarının Maliye Bakanlığı tasarrufuna geçmiş olması, bu alanlara alınıp satılan bir meta olarak bakılmakta olduğunun açık bir göstergesidir. 3402 sayılı Kadastro Kanununun Ek 4 üncü maddesi gereğince güncelleme veya kullanım kadastrosu çalışmaları tamamlanarak Maliye Bakanlığına (Milli Emlak Genel Müdürlüğü) teslim edilen 59l.63I adet 2/B taşınmazı bulunmaktadır (Torun, 20I3). Kanunun önemli tanımlamalarından biri, "Proje alanı" tanımıdır. Bu tanıma göre proje alanı,
2/B alanlarını ve proje bütünlüğünü sağlamak amacıyla gerektiğinde bu alanların dışında kalan yerleri de kapsayan ve sınırları Çevre ve Şehircilik Bakanlığı, Toplu Konut İdaresi Başkanlığı veya ilgili büyükşehir ya da diğer belediyelerce belirlenen ve Çevre ve Şehircilik Bakanlığınca onaylanan gecekondu veya kentsel dönüşüm projesi uygulanacak alanlardır. Özetle, yalnızca 2/B alanlarında değil, bunların çevrelerinde de, orman bütünlüğü açısından ciddi bir tehdit oluşturacak şekilde, TOKi ve Çevre ve Şehircilik Bakanlığı'nca kentsel dönüşüm uygulamaları gerçekleştirilmesi olanaklı kılınmıştır. Bu durum ayrıca, Orman ve Su İşleri Bakanlığı'nın 2/B alanlarında yetkisizliğinin de bir göstergesidir. Orman ve Su İşleri Bakanlığı gibi, alanda tek yetkili olması gereken bir kurumun herhangi bir nedenle orman vasfını kaybettiği iddia edilse de, tüm yargı kararlarına göre orman sayılan alanlarda yetkisiz kılınması anlaşılır bir tutum değildir. Kanun, Çevre ve Şehircilik Bakanlığı'nı daha da güçlendirecek ve bu alanlarda uygulama yapmalarını olanaklı kılacak şekilde, orman olarak muhafazasında bilim ve fen bakımından hiçbir yarar görülmeyen, aksine tarım alanına dönüştürülmesinde yarar olduğu tespit edilen yerlerden, sınırları Bakanlar Kurulunca belirlenen alanların; baraj veya gölet rezervuar alanları ile içme suyu maksatlı barajların mutlak koruma alanlarında, askeri yasak bölgelerde, deprem veya erozyon ya da heyelan tehlikesi bulunan alanlarda kalmaları sebebiyle bulundukları yerleşim yerlerinden kaldırılmaları zorunlu bulunan Devlet ormanları içinde veya bitişiğinde bulunan köy ve mahalle halkının iskânlarının temini için, orman sınırları dışına çıkartılarak tapuda Hazine adına tescil edileceğini ve bu alanların Çevre ve Şehircilik Bakanlığının tasarrufuna geçeceğini hükme bağlamıştır.

Konuya sürdürülebilirlik açısından yaklaşan Erdönmez (20I3), şu eleştirileri yöneltmektedir:

- Satışa konu olan alanlar kökeninde ormandır ve satış yoluyla bir daha orman olma ihtimali bütünüyle ortadan kalkmaktadır.

- Böylelikle hem orman alanlarının hem de orman kaynaklarının niteliksel yapısının devamlılı̆ı yara almaktadır.

- Orman kaynaklarından hemen tüm toplumsal gruplar ve tüm sektörler fayda sağlamaktadır. Orman alanlarının orman sınırları dışarısına çıkarılması ve buna neden olan sektörlere (tarım, turizm, endüstri, kentleşme vb.) satışının yapılması orman kaynaklarından beklentileri olan farklı toplumsal gruplar ve sektörler arasında adaletsizliğe yol açmaktadır.

- Bunlardan daha önemlisi ise yasadışı yöntemlerle ormanlara zarar veren gerçek ve tüzel kişilerin bu uygulamadan karlı çıkmış olmalarıdır. Böylelikle yasaların caydırıcılığı ortadan kalkmakta ve yeni orman tahriplerinin önü açılmaktadır.

22 MADDE 35- 4706 sayılı Kanunun geçici 4'üncü maddesinin ikinci fıkrası aşağıdaki şekilde değiştirilmiştir: "Bu madde kapsamında Hazine adına tescil edilen taşınmazlar, büyükşehirlerde öncelikle büyükşehir belediyelerine, büyükşehir belediyelerinin talebinin olmaması halinde ilgili belediyelere, diğer yerlerde ilgili belediyelere bedelsiz olarak devredilir. Bu taşınmazların yapı sahiplerine satışı ve genel hükümlere göre değerlendirilmesi bu Kanunun 5 inci maddesine göre yapılır." 
6292 sayılı Kanun, 2/B alanlarının satış koşullarını da ayrıntılı olarak düzenlemiştir. Buna göre, 2/B alanlarında bulunan taşınmazların 3 I/I2/20II tarihinden önce kullanıcısı ve/veya üzerindeki muhdesatın sahibi olan kişilerin, taşınmazların satış bedeli rayiç bedelin yüzde yetmişi olmak üzere bu taşınmazları satın alabilmelerine olanak tanınmıştır. Bunu yanı sıra, Hazineye ait tarım arazilerini; 3I/I2/20II tarihi itibarıyla en az üç yıldan beri tarımsal amaçla kiralayan, kira sözleşmesi halen devam eden kiracılara veya bu arazileri aynı süreyle tarımsal amaçla kullanan ve kullanımlarının halen devam ettiği idarece belirlenen kullanıcılara ya da paydaşlara da bu arazileri bedeli karşılığında, diğerleriyle aynı koşullarla satışı olanaklı kılınmıştır.

6292 sayılı yeni yasayla zemini hazırlanan 2/B Alanlarının satışı konusu, bugün kamunun resmi internet sayfalarında "büyük firsat", "tarihi bir firsat" olarak nitelendirilmekte, herhangi bir ürün satışı gibi görülmekte, indirime konu edilerek, reklam ve pazarlama yoluyla satışlar cazip kılınmaya çalışılmaktadır.

2012 Yılında çıkan ve orman sorununu daha da derinleştirmek üzereyken, 2014 yılında Anayasa Mahkemesi kararıyla bazı maddeleri iptal olan bir başka kanun, 6306 sayılı Afet Riski Altındaki Alanların Dönüşümü Hakkında Kanun'dur. Kanun yürürlüğe girdiğinde, birçok Kanun ile birlikte "683I sayılı Orman Kanunu'nun, 6306 sayılı Kanunun uygulanmasını engelleyici hükümleri ve diğer kanunların bu Kanuna aykırı hükümleri uygulanmaz" şeklinde düzenlenmiş olan maddesi 2014 yılında Anayasa Mahkemesi kararıyla iptal olmuş, orman alanlarını yapılaşmaya açacak çok önemli bir hatadan dönülmüştür. Aynı Kanun, ayrıca Orman Kanunu'na ek 13. Maddeyi eklemiş, bu maddeyle "Şehrin içindeki veya yakın çevresindeki ormanlık alanların afetler öncesinde piknik alanı, mesire yeri ve afet sonrasında geçici barınma yeri olarak kullanılması için Orman Genel Müdürlüğünce veya bu Genel Müdürlüğün uygun görmesi hâlinde talepte bulunan idarelerce altyapı hizmetleri verilir." denilerek, yine de orman alanlarının yapılaşmaya açılabileceğini hükme bağlanmıştır.

Orman sınırları dışına çıkarılan yerler ile ilgili süreç, görüldüğü üzere oldukça uzun ve karmaşıktır. Başpınar (1999) bu durumu şöyle açıklamaktadır: Orman sınırlan dışına çıkarılan yerlerin hukuki durumunun doğru tespiti için, bu işlemin, hangi kanun döneminde yapıldığının açıkça belirtilmesi gerekir. Bu nedenle, söz konusu işlem hakkında 1744 sayılı Kanun, 2896 sayılı Kanun veya 3302 sayılı Kanun dönemi olmak üzere bir ayrım yapmak gerekir. Ona göre ayrım şu şekilde olmalıdır:

- Orman sınırı dışına çıkartma işlemi 0I.01.1984'den önce yapılmışsa;

1744 sayılı Kanuna göre, Kanunun yürürlüğe girdiği 20.6.1973 tarihi ile 2896 sayılı Kanun'un yürürlük tarihi olan 0I.0I.1984 tarihine kadar, tapulu olup da, Orman Kanunu'nun m. 2/B uygulaması ile orman sınırları dışına çıkarılan şahıslara ait yerler, yine eski sahipleri adına tescil olunur. Buna karşılık, tarım arazisi olması nedeniyle orman sınırı dışına çıkarılan yer, tapusuz ise, çıkarma işlemi Hazine adına yapılmalıdır.

- Orman sınırı dışına çıkartma işlemi 01.01.1984'den sonra yapılmışsa;

0I.0I.1984 tarihinde yürürlüğe giren 2896 sayılı Kanuna göre orman sınırı dışına çıkarılan yerler, daha önce Devlet ormanı ise Hazine adına, tüzel kişiliğe sahip kamu kurumuna ait orman ise söz konusu kurum adına, özel orman ise sahipleri adına tescil edilir.

Bu oldukça açık olan hukuki sınıflandırmaya rağmen, 1984 yılından çok sonra bile, orman sınırı dışına çıkartılıp lüks yerleşmelere dönüşen alanların sayısı hızla artmaya devam etmiştir. 2012 tarihli ve 6292 sayılı yasa da süregelen bu gelişme eğilimini bedeli karşılığında meşrulaştıracak ve yargı kararlarının "orman” olarak nitelendirdiği birçok alan, bundan böyle yasal yapılaşmış alanlara dönüşecektir. 2/B sorununun çözümünün, bugüne dek getirilen onlarca imar affı modelinde arandığı açıktır. Dahası, bu alanlar, proje alanı adı altında, üstelik kamu eliyle mevcut durumun da üzerinde yoğunluklarla yapılaşmaya açılacaktır.

2/B maddesine göre orman sınırları dışına çıkarılan yerlerin geometrik ve hukuki durumlarının tayin ve tespiti ile bu suretle sınırlandırılan ormanların ve orman sınırları dışına çıkartılan alanların tapu siciline tescillerini sağlamak ve orman kadastro bilgi sisteminin altlı̆ını oluşturmak amacıyla, Orman Kadastrosu ve 2/B Uygulama Yönetmeliği 20.I I.20I2/ 28473 tarih ve sayılı Resmi Gazete'de yayınlanarak yürürlüğe girmiştir. Bu Yönetmelik, bir yerin kasaba ve şehir toplu yerleşim alanı olarak orman sınırları dışına çıkarılabilmesi için 31.12.198I tarihinden önce bilim ve fen bakımından orman niteliğini tam olarak kaybetmiş olması ve özel iş yerlerini, kamu hizmeti gören bina ve tesisleri ihtiva eden arsa toplulukları ile bu toplulukların içinde veya kenarında yol, alan veya arsa haline dönüşmüş yerler veya bunların devamı haline gelmiş yerlerden olmasını şart koşmaktadır.

Son olarak 18.05.20I8 tarihinde yürürlüğe giren Vergi Ve Diğer Bazı Alacakların Yeniden Yapılandırılması İle Bazı Kanunlarda Değişiklik Yapılmasına İlişkin Kanun ile 6292 sayılı Kanuna göre daha önce Maliye Bakanlığınca satılan taşınmazların rayiç bedelleri emsal alınarak satışa konu edilmesi mümkün kılınmıştır.

\section{Orman Sınırları Dışına Çıkartılmış Alanlarda Planlama ve İstanbul'da 2/B Çıkmazı}

Önceki bölümde kronolojik olarak aktarılmaya çalışılan mevzuattaki gelişmeler, sorunun ne derece karmaşık ve büyük olduğunu açıkça ortaya koymaktadır. Bu yasal kaos içerisinde planlama süreci de doğal olarak ciddi bir açmazla karşı karşıya bulunmaktadır. Bir tarafta yıllar boyu sistematik bir şekilde yok edilen orman alanları, diğer tarafta bu yasal kaosun lehi- 
ne işlediği, hak sahipliği edinmiş ve beklenti içinde olan özel kişiler, sorunu içinden çıkılamaz bir noktaya taşımıştır. Kuşkusuz sorun yalnızca 2/B alanlarının durumundan kaynaklanmamaktadır. Planlama süreçlerinin karmaşıklığı, planlar arası hiyerarşinin sıklıkla tersten işlemesi ya da hiç olmaması, üst ölçek planların eksikliği, birbirini yok sayan, delen planlar 2/B kaosuna hep birlikte katkıda bulunmaktadır.

Bu sürecin bir başka boyutu ise, küreselleşerek yayılan kapitalizmin doğal varlıkların ekonomiye kazandırılması adına orman alanları üzerinde kurduğu baskı ile ilgilidir. Turan ve Bayram (20l0), küresel kapitalizme eklemlenme sürecinde ülkemize biçilen yeni rolün gereği olarak, topraklar ve doğal varlıkların ekonomiye kazandırılması" adı altına yürütülen politikayı gündeme getirerek, bu politikanın araçlarından olan menkulleştirme tehdidine dikkat çekerler ve menkulleştirmenin yakın bir gelecekte bütün doğal varlıkların ve devlet tarafından sunulan kamusal hizmetlerin özelleştirilmesine yol açacağını öne sürerler. Ormanların yanısıra, daha birçok doğal kaynak ve altyapı hizmetinde özelleştirmelerin, bu varlıklar üzerindeki mülkiyet ve egemenlik ilişkilerini değiştireceği vurgularlar.

\section{I. İstanbul'da 2/B Arazilerinin Mevcut Durumu ve 2/B Çıkmazı}

İstanbul, 2/B arazileri üzerinde en fazla yerleşim alanı bulunan illerden biri olarak bu sorundan birincil derecede etkilenen bir konumdadır. İstanbul, ülkemizde 2/B alanları sıralamasında, I8.233 ha ile7. sırada yer almaktadır. Ancak 2/B arazileri üzerinde en fazla yerleşim alanı bulunan illerdendir. İlin 2/B alanları büyük ölçüde kuzey bölgesinde yoğunlaşmıştır. Başta Beykoz, ardından Sarıyer, Çatalca ve Şile olmak üzere birçok ilçe, 2/B sorunu ile karşı karşıyadır (Şekil I).

İstanbul'da 2/B alanlarının mevcuttaki kullanım durumuna bakıldığında, I8.233 hektarlık bir alanın yerleşim yeri olarak kullanıldığı ve bu oranın 242.200 hektarlık İstanbul ormanlarının ${ }^{23}$ \% I0'una yakın olduğu görülmektedir (Tablo 4). ${ }^{24}$

İstanbul'un, Adalar, Beykoz, Eyüp, Gaziosmanpaşa, Kağıthane, Kartal, Küçükçekmece, Maltepe, Pendik, Sarıyer, Şişli, Tuzla, Ümraniye, Üsküdar, Çatalca, Silivri, Sultanbeyli ve Şile olmak üzere toplam 18 ilçesinde 2/B arazisi bulunmaktadır. Bunların arasında ilk sırada 3379 hektarlık araziyle Beykoz gelmekte, bunu 1949 hektarlık alanla Ümraniye ve 1944 hektarlık alanla Silivri izlemektedir.

\section{2. İstanbul'a Özel Düzenlemeler}

Orman alanlarının orman sınırını dışına çıkartılmasını olanaklı kılan tüm bu yasal gelişmeler içerisinde, İstanbul'u doğrudan ilgilendiren birçok düzenleme, kentin orman alanlarının yapı-

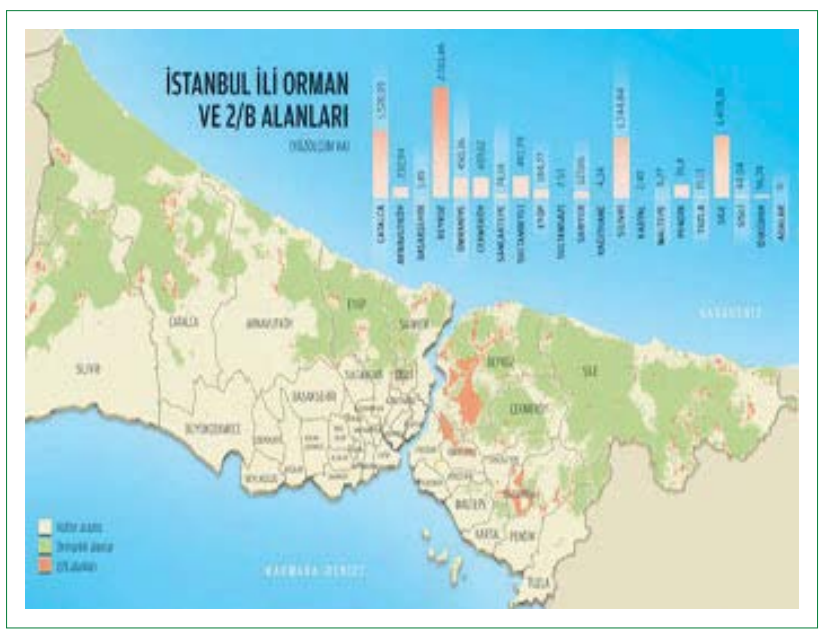

Şekil I. İstanbul'un 2/B alanları. Kaynak: http://www.milliyet.com.tr/ istanbul-un-2b-satisindan- 16-2-milyar-lira-bekleniyor-ekonomi- |437940/

laşmaya açılmasının zeminini de hazırlamıştır. 1980'li yıllarla birlikte başlayan bu süreç, 1990'larda hızlanarak sürmüş ve orman alanları içinde özellikle üst gelir grubuna yönelik toplu yerleşim alanları ormanların yoğun yapılaşma ve yoğun nüfus baskısı altına girmesine yol açmıştır.

İstanbul'un planlama geçmişinde orman alanlarının durumuna bakıldığında, İstanbul'un 1980 tarihli ve I/50.000 ölçekli Nazım Planı'nın, kentin kuzey bölgesinin ormanlarının, su havzaları ve tarım alanlarıyla birlikte korunmasını ve rekreasyonel amaçla kullanılmasını hedeflemiş olduğu görülmektedir. Buna karşılık, Boğaziçi Kanunu'nun da yürürlüğe girdiği 1983 yılı sonrasında, Nazım planlar ile koruma alanı olarak belirlenen bu orman alanlarının büyük bir talana konu edildiği görülmektedir.

Boğaziçi Kanunu, 3194 sayılı İmar Kanunu'nu 47. Maddesinden gelerek yerine işlenen maddeleriyle, İstanbul'daki orman alanlarını 4. Maddesinde düzenlemektedir. Buna göre, Boğaziçi Alanı sınırları içinde Devlet ormanı statüsüne alınacak yerler, Boğaziçi İmar Yüksek Koordinasyon Kurulunca kararlaştırılır ve kamu kurum ve kuruluşlarına ait olanlar bedelsiz olarak Hazineye devredilir. Özel mülkiyete ait olanlar ise Tarım ve Orman Bakanlı̆̆ınca kamulaştırılır. Devlet ormanı statüsüne alınan bu yerler, Tarım ve Orman Bakanlığınca hazırlanacak proje ve programa göre Boğaziçi Alanının doğal yapısına uygun olarak düzenlenir, ağaçlandırılır; parklar ve mesire yerleri yapılır ve bunların bakımı, işletilmesi ve muhafazası sağlanır. Devlet ormanı statüsüne alınan bu yerlerde 683I sayılı Orman Kanunu'nun 2 nci maddesi uygulaması yapılamaz. Boğaziçi Alanı içindeki ormanlarda intifa ve irtifak hakkı tesis edilemez. Ancak bu Kanunun amacına uygun intifa ve irtifak hakkı, Boğaziçi İmar İdare Heyetinin teklifi üzerine ilgili bakanlıklarca tesis edilebilir.

${ }^{23}$ İstanbul Orman Bölge Müdürlüğü görev alanı içinde yalnızca İstanbul iline ait kısımdır.

${ }^{24}$ Harita ve Kadastro Mühendisleri Odası'nın 2009 yılında yaptıkları basın açıklamasında bu oran I62,67 km²; yani orman alanlarının \%3.0'i olarak görülmektedir. 
İstanbul'un en özel bölgelerinden biri olan Boğaziçi Alanı'nın 1974 yılında Doğal ve Tarihi Sit Alanı olarak ilan edilmesi, ${ }^{25}$ 1983'de Öngörünüm, Geri Görünüm ve Etkilenme Bölgesi Sit Alanları tescili, ${ }^{26}$ bu kararların I/5000 ve I//000 ölçekli planlara işlenmesini sağlamış; ancak plan kararları ve ilgili Yasa'daki hükümler Boğaziçi'nde yer alan orman alanlarını korumada yeterli olamamıştır.

1985 yilında İmar Kanunu'na eklenen ve Boğaziçi Kanunu'na işlenen 47. madde gereğince birçok koru alanı yapılaşmaya açıımıştır. Erdem'in henüz 1997 yılında yayınladığı çalışması, sorunun boyutlarını ortaya koymaktadır. Çalışmaya göre, o dönemde Beşiktaş ilçesinde bulunan toplam $542.193 \mathrm{~m}^{2}$ lik koru alanının \%।4,6'sı 3194 sayılı Boğaziçi Yasası'nın 47. maddesiyle konuta açılmıştır. Yine toplamda $363.255 \mathrm{~m}^{2}$ olan koruya katılacak alanların \%20'si 47. madde uyarınca konuta açımıştır. Sarıyer ilçesindeki koru alanlarının toplamı 2.04I.700 $\mathrm{m}^{2}$ 'dir. 47. Madde ile konuta açılan koru alanlarının toplamı ise $278.700 \mathrm{~m}^{2}$ olarak belirlenmiştir. Sarıyer'de Uygulama İmar Planı uyarınca I.665.152 $\mathrm{m}^{2}$ lik koruya katılacak alanların $486.700 \mathrm{~m}^{2}$ 'si 47. madde kapsamında konuta açılmıştır. Beykoz ilçesinde yer alan toplam I.I59.988 m² koru alanının \%5,6'sı 47. Madde uyarınca konuta açılmıştır. Üsküdar'da ise 136.926 $\mathrm{m}^{2}$ lik koruya katılacak alanın $10.000 \mathrm{~m}^{2}$ 'si 47. madde uyarınca konut alanı olarak kullanılmaktadır.

1995 yılına gelindiğinde, Beykoz ve Sarıyer ilçelerinde 1980 Nazım Planı çerçevesinde korunması gerekli doğal bölgeler olarak belirtilen alanların, Beykoz için, İstanbul Kuzey Kesimi Karadeniz Kuşă̆ı I No'lu Doğal Sit Alanı ve Sarıyer için İstanbul Kuzey Kesimi Karadeniz Kuşağı 2 No'lu Doğal Sit Alanı olarak tescil edilmesi, ${ }^{27}$ orman alanlarının koruma altına alınması konusunda çok önemli bir adım olarak karşımıza çıkmaktadır.

1926 yılında "Kasapçayırı Özel Ormanı olarak tasdik edilen Sarıyer bölgesi ormanları içinde inşa edilen Uyum Villaları, orman alanlarının yapılaşmaya açılmasının ilk örnekleri arasında yer alır. Turgut Özal hükümeti döneminde, 3194 sayılı İmar Yasası'na eklenen 47. maddeyle Boğaziçi Öngörünüm Bölgesi kısmi yapılaşmaya açıımışıı. Bu kararla 1985 yııında 130 villanın inşaatına başlanmıştır. Anayasa Mahkemesi bir yıl sonra ek maddeyi İmar Yasası'na aykırı bularak iptal etmiş, ancak kararın Resmi Gazete'de yayımlandığı Nisan 1987'ye kadar 107। blok için daha ruhsat verilmiştir. Daha sonra başlatılan hukuki süreç ise, villaların tamamının yıkılmasını sağlayamamış, yıkılan villalar metruk halde durmaya devam etmiştir.

Yine, 2700 dönüm devlet ormanının Kemer Country'ye 'golf alanı' olarak tahsis edilmesi, İstanbul'da orman alanlarının tah-

\footnotetext{
${ }^{25}$ GEEAYK 14.12.1974 - 8172.

${ }^{26}$ GEEAYK 24.06.1983 - 15175

27 i̇st. III No'lu KTVKK I5.II.1995 - 7755.
}

rip ve talanının öncü örnekleri arasında sıralanabilir. $18 \mathrm{Kasım}$ 199 I'de ormanlık sahada 18 delikli golf sahası, 670 yataklı otel ve bungalov tipi moteller, atlı spor tesisleri ile halka açık turistik tesis yapmak için Orman Bakanlığı'ndan, şimdi Kemer Golf \& Country Club'ın oluştuğu arazi 49 yıllığına kiralanmıştır. Göktürk beldesi sınırları içerisindeki ormanlık alanın 1992'de, başkalarına da devri mümkün olmak üzere özel bir şirkete devrinin ardından, turistik tesislerin sınıfı ve yapılaşma hakları artırılmış, kamuya açık olması gereken alan, kulüp üyelerine tahsis edilmiştir. Şirket, turizm tesisi kurmak gerekçesiyle kiraladığı orman arazisine 168 lüks villa yapmıştır. 2004 yılında Eyüp Cumhuriyet Başsavcılı̆ı'nca bir ihbar üzerine başlatılan soruşturmada, turistik amaçla tahsis edilen devlet ormanında inşa edilen villaların el değiştirdiği belirlenmiştir. 2019'da golf alanı olarak kullanılan alanların bu kez Çevre ve Şehircilik Bakanlığı 4 Eylül 2018 tarihli karar ile İstanbul'un Eyüpsultan ilçesine bağı Göktürk Mahallesi'nde Kemer Country yerleşkesindeki bazı parseller imar planı değişikliği ile yapılaşmaya açılmıştır. İdare Mahkemesi, kamuya aykırı bulmamışır.

Bir başka gelişme olarak, Sarıyer ilçesinin mücavir alanı içinde yer alan 7 köyün Bahçeköy beldesine bağlanmasının ardından, \%9l'i devlet ormanı olan 81 bin dönüm Sit alanının İstanbul'un Nazım Planlarında öngörülen sit alanı sınırları dışında bırakılması gösterilebilir (Acun, 1998). Böylece dönemin Büyükşehir Belediye Yasası gereği, Büyükşehir belediyesinin her türlü planlama ilkesi ve denetimden uzak bir şekilde, belde belediyesinin yetki alanında yeralan bu alanlarda, bir vakıf üniversitesi hızla ruhsat alarak inşaata başlamıştır.

2003 yılında statüsünde olan ve getirilen kararlarla tamamı yapılaşan Acarkent projesi, dönemindeki gelişmelerin en çarpıcı örneklerinden biridir. Boğaziçi Beykoz Saip Molla Ormanı'nda yaşanan sürecin sonunda $2.291 .220 \mathrm{~m}^{2}$ lik alanın tamamı villalara tahsis edilmiştir.

Bu gelişmenin hemen ardından, yine Beykoz'da bir başka proje hayata geçirilmiştir. Beykoz Belediyesi'nin 10 Nisan 2003 tarihli, Özel Serdaroğlu Ormanı içerisinde yapılaşmaya izin veren yapı ruhsatının ardından hızla başlayan Acar İstanbul projesi için, büyük bir yasal karmaşayı ve çelişkili kararları içeren bir sürecin sonunda, İstanbul 3. İdare Mahkemesi'nin 2005 yılında "inşaatların durdurulmasına" ve "Beykoz Belediyesi'nin, Çevre ve Orman Bakanlığı'nın kesin izni olmadan verdiği yapı ruhsatlarının iptaline" karar vermesi ve Danıştay 6. Dairesi'nin de kararı onamasıyla "yıkım" kararı kesinleşmiştir. Bununla birlikte yıkım gerçekleşmemiştir. Birçok 2/B alanı, örneklerde de görüldüğü üzere dava konusu olmuş; ancak bu davaların sonucunda, Uyum villaları ve Acar İstanbul örneğinde olduğu gibi, bu alanlar tekrar orman alanına dönüşmemiştir. 
İstanbul'u konu alan yakın tarihli yasal düzenleme de, geçmişte bir 2/B alanından türemiş bir ilçe olan ve sorunlar artarak devam eden Sultanbeyli İlçesinde bulunan bazı alanlarda yürütülecek iyileştirme, yenileme ve dönüşüm uygulamaları kapsamında Çevre ve Şehircilik Bakanlığı ile Maliye Bakanlı̆ıını yetkilendiren 26.09.20II tarihli Bakanlar Kurulu Kararı'dır. ${ }^{28}$ Karar ile Sultanbeyli'de iyileştirme, yenileme ve dönüşüm uygulamaları yapılması, taşınmazların kamulaştııııması için TOKi ve Çevre ve Şehircilik Bakanlı̆̆ıve üçüncü kişilere devredilmesi için, yine Çevre ve Şehircilik Bakanlığı yetkilendirilmiştir. Uygulamalar için gerekli ödenek, Maliye Bakanlığı bütçesine konacaktır. Böylelikle Sultanbeyli ilçesinde dönüşüm uygulamalarının önü açılmış olmakta ve ormandan dönüşen bu alan kamu eliyle meşrulaştırımaktadır.

18.05.20|8 tarihinde yürürlüğe giren Vergi Ve Diğer Bazı Alacakların Yeniden Yapılandırılması Ile Bazı Kanunlarda Değişiklik Yapılmasına İlişkin Kanun 2960 sayılı Boğaziçi Kanununda tanımlanan Boğaziçi Sahil Şeridi Ve Öngörünüm Bölgesi içinde ekli kroki ile listede sınır ve koordinatları gösterilen alanı kapsam dışı bırakmış olsa da, arkasından bu düzenlemeye ek olarak, Boğaziçi Öngörünüm Bölgesi Ve Sahil Şeridinin imar affı düzenlemesi kapsamına alınmasını sağlayacak kanun teklifinin Meclise sunulmuştur. Kanun Teklifinde, "3194 sayılı İmar Kanunu'nun geçici 16. Maddesinin dördüncü fikrasına "bu Kanun" ibaresinden sonra gelmek üzere "ve 2960 sayılı Kanun" ibaresi eklenmiş ve 2960 sayılı Boğaziçi Kanunu'nda tanımlanan Boğaziçi Sahil Şeridi Ve Öngörünüm Bölgesine ait kroki ile sınır ve koordinat listesi ekteki gibi değiştirilmiştir" denilmektedir. Buna göre, yapılan ek ile geçici 16. Maddenin dördüncü fıkrası "Yapı Kayıt Belgesi verilen yapılarla ilgili bu Kanun ve 2960 sayıı Kanun uyarınca alınmış yıkım kararları ile tahsil edilemeyen idari para cezaları iptal edilir." şekline gelmektedir. Bu çalışmanın tamamlandığı tarih itibariyle henüz meclisten geçmemiş olan bu düzenlemenin yasallaşması halinde, Boğaziçi sınırları içindeki ormanlık alanlardaki izinsiz yapılaşmalar da af kapsamına girecektir. Yasal sürecin daha kolay okunabilmesi için Tablo 3 düzenlenmiştir.

Görüldüğü üzere, orman sınırı dışına çıkarma süreci oldukça uzun bir zaman aralığına yayılmıştır. Süreç dönemsel bir incelemeye tabi tutulduğunda, 1970'lere kadar genel itibariyle ormanlar üzerinde daha korumacı bir politika benimsendiği, orman sınırı dışına çıkarma işlemlerinin daha çok savaş ve yokluktan etkilenen köylülerin temel ihtiyaçlarını gidermeye dayandığını, refah devleti döneminde kamu yararı kavramı vurgusunun güçlü olduğunu söylemek mümkündür. 1970'lerden sonra ve özellikle neo-liberal politikaların kamu yararı yerine özel yararı öne çıkardığı 1980'li yıllarda orman alanlarının sınırlarının giderek daraltıılığı, yapılaşmaya konu edildiğini ve yasal düzenlemelerin de bu politikayı desteklediği gözlemlenmektedir. 1982 Anayasası, yasadışı yapılaşmayı destekleyen 5.
Beş Yıllık Kalkınma Planı ve yeni küresel dünya düzenine ayak uydurmayı hedefleyen, neoliberal dille yazılmış kentin yeni yasaları el birliği ile orman alanlarının daraltılması ve yapılaşmaya konu edilmesinde rol oynamışlardır. 1950'lerden başlayarak 1980'lerde hızlanan popülist politikalar da sürecin önemli bir tetikleyicisi olmuştur. 2000'li yıllardan başlayarak, orman arazilerinin orman sınırı dışına çıkartılarak satışı ve dönüşümü konusunda yasal düzenlemeler hız kazanmış, finansal modellerle çözüm süreç mega projelerin orman alanlarını yok ederek gelişmesiyle daha da büyük boyutlara ulaşmıştır. Bu dönemi ormanların sadece satış ile değil, kentsel dönüşüm ve mega ulaşım projeleri ile de tahrip olunarak yok edildiği bir dönem olarak tarif etmek mümkündür. Satış ve özelleştirmelerin artırılması sonucu kamu kaynaklarının giderek tüketilmesi, elde kalan son kamu mallarının satışını son çare ekonomi modeli olarak ortaya atmış, özellikle seçim dönemleri yaklaşırken yürürlüğe konan imar afları, her geçen gün orman alanlarının rant odaklı gayrimenkul projelerine servis edilerek, daha fazla tahrip ve yok olmasına sebep olmuştur.

\subsection{Planlama Sürecinde 2/B Arazileri ve İstanbul}

Orman sınırları dışına çıkartılan alanlarda planlama, geçmişten bugüne çözümsüz bir sorun olarak süregelmiştir. Üst ölçekten ya da noktasal olarak gelen plan kararları, kentlerin temel doğal yaşam alanları olan orman alanlarının büyük ölçüde tahribine yol açmışır. Yine, orman kadastrosundan kaynaklı birtakım sorunlar nedeniyle kadastro çalışmaları sürecinde orman alanlarının şahıslar adına tescil edildiği (Şimşek, 2010), böylelikle bu alanların orman sınırları dışında kaldığı ve hak sahipliğine konu olduğu bilinmektedir.

3194 sayılı İmar Kanunu ve yönetmelikleri, belediye sınırları içinde veya dışındaki tümarazilerin, yürürlükte bulunan her ölçekteki imar planı kararlarına aykırı kullanılamayacağını ve tasarruf edilemeyeceğini hükme bağlamıştır. Bu düzenlemeye bağlı olarak, orman sınırları dışına çıkartılan alanların, yerleşmeye ve konut kullanımına uygun plan kararı alınmadan satılmaları mümkün değildir. İmar planı kararlarıyla 2/B arazileri çeşitli kamu hizmetlerine tahsis edilebilmektedirler; ancak bu durumda bu arazilerin kullanıcılarına satılması planlama ilkelerine aykırıdır. Hak sahipliğinden kaynaklanan sorunlar nedeniyle yasal durumları netleştirilemeyen alanlar giderek artmış, böylelikle 2/B sorunu çözümsüzlüğe her geçen gün biraz daha yaklaşmıştır.

İstanbul, 1940'ların sonlarından başlayarak, birçok sosyo-ekonomik ve mekânsal sorunla karşı karşıya kalmıştır. Hızla artan göç, nüfus ve yapılaşma baskısı İstanbul'un temel kentleşme sorunlarının temelini oluşturmuş, neredeyse hız kesmeden bugüne dek gelmiştir. İstanbul üzerindeki yapılaşma baskısı, 2. Dünya Savaşı'nın ardından yapılan İstanbul Sanayi Planlarına koşut

${ }^{28}$ Karar Sayısı : 201 I/2266. 
Tablo 3. Orman sınırı dışına çıkarma süreci

\begin{tabular}{lll}
\hline Tarih & Mevzuat & Düzenleme \\
\hline II.10.1920 & 39 sayılı Baltalık Kanunu & $\begin{array}{l}\text { Yoksul Anadolu köylüsüne hane başına } 20 \text { dönüm orman alanı } \\
\text { verilmesi }\end{array}$ \\
$\begin{array}{ll}4785 \text { sayılı, 3116 sayılı Orman Kanunu'na Bazı Hü- } \\
\text { 09.07.1945 }\end{array}$ & $\begin{array}{l}\text { Özel ormanları devletleştirilmesi } \\
\text { kümler Eklenmesine ve Bu Kanunun I. Maddesinde }\end{array}$
\end{tabular}

24.03.1950 5653 sayılı Orman Kanununun Bazı Maddelerinin Değiştirilmesine ve Bu Kanuna Bazı Maddeler Eklenmesine Dair Kanun

31.08 .1956

1961

683I sayılı Orman Kanunu

T.C. Anayasası

14.07.1970

I 255 sayılı Türkiye Cumhuriyeti Anayasası'nın I 3 I'inci maddesinin Değiştirilmesine Dair Kanun

20.06.1973

1744 sayılı 683। Sayılı Orman Kanununun Bazı Maddelerinin Değiştirilmesine ve Bu Kanuna 3 Ek Madde ile bir Geçici Madde Eklenmesine Dair Kanun

TC Anayasası
2896 sayılı 31/8/I956 Tarihli ve 683 I Sayılı Orman Kanununun Bazı Maddelerinin Değiştirilmesine ve Bazı Maddelerinin Yürürlükten Kaldırılmasına İlişkin Kanun
03.04. 1950 tarihine kadar orman niteliğini kaybetmiş olan yerlerin orman sayılmaması, bu yerlerden tapusuz olanların zaman aşımı yoluyla kazanılabilmesi, tapulu olanların özel orman sayılması Orman vasfını kaybeden alanların orman sınırı dışına çıkartılması “Kamu yararı"nı esas alan korumacı bir yaklaşımın benimsenmesi, Devlet ormanlarının Devletçe yönetilip işletilmesi, bu ormanların mülkiyeti, yönetimi ve işletilmesinin özel kişilere devrolunamaması, zamanaşımıyla mülk edinilememesi ve kamu yararı dışında irtifak hakkına konu olamaması

196I Anayasasının I31. Maddesinin değiştirilmesi

"Anayasanın yürürlüğe girdiği tarihten önce bilim ve fen bakımından orman niteliğini tam olarak kaybetmiş olan tarla, bağ, meyvelik, zeytinlik gibi çeşitli tarım alanlarında veya hayvancıIıkta kullanılmasında yarar bulunan topraklarla; şehir, kasaba ve köy yapılarının toplu olarak bulunduğu yerler dışında orman sınırlarında hiçbir daraltma yapılamaz" maddesiyle orman sınırları dışına çıkartılmanın önünün açılması

6831 sayılı Orman Kanunu'nun 2. maddesinin değiştirilmesi

“15.10.196I gününden önce bilim ve fen bakımından orman niteliğini tam olarak kaybetmiş yerlerden; a) Su ve toprak rejimine zarar vermeyen, orman bütünlüğünü bozmayan tarla, bağ, meyvelik, zeytinlik, fındıklık, fıstıklık (antepfıstığı) gibi çeşitli tarım alanlarında ve hayvancilıkta kullanılmasında yarar bulunan yerler ile otlak, kışlak ve yaylak haline gelmiş yerler, b) Şehir, kasaba ve köy yapılarının toplu olarak bulunduğu yerleşim sahaları orman sınırları dışına çıkarılır" maddesiyle 2/B uygulamalarının önünün açılması "Orman olarak muhafazasında bilim ve fen bakımından hiçbir yarar görülmeyen aksine tarım alanlarına dönüştürülmesinde kesin yarar olduğu tespit edilen yerler ile, 31.12.198I tarihinden önce bilim ve fen bakımından orman niteliğini tam olarak kaybetmiş olan tarla, bağ, meyvelik, zeytinlik gibi çeşitli tarım alanlarında veya hayvancılıkta kullanılmasında yarar olduğu tespit edilen araziler, şehir, kasaba ve köy yapılarının toplu olarak bulunduğu yerler dışında orman sınırlarında daraltma yapılamaz".

Orman koruma politikasından vaz geçilmesi

Orman sınırları dışına çıkartma işlemlerinin yürütülmesine ilişkin 1744 sayılı kanunda belirtilen 10 yıllık sürenin kaldırılması, sürecin önünün sınırsızca açılması 
Tablo 3 (devamı). Orman sınırı dışına çıkarma süreci

\begin{tabular}{ll}
\hline Tarih & Mevzuat \\
\hline I7.10.1983 & $\begin{array}{l}2924 \text { sayılı Orman Köylülerinin Kalkınmalarının Des- } \\
\text { teklenmesi Hakkında Kanun }\end{array}$
\end{tabular}

Düzenleme

22.05.1986 3290 sayılı "24.2.1984 Tarih ve 298I Sayılı Kanunun Bazı Maddelerinin Değiştirilmesi ve Bu Kanuna Bazı Maddeler Eklenmesi Hakkında Kanun" un değişik geçici 2. maddesinin (e) bendi

19.06.1987 3302 sayılı 31.8.1956 Tarihli ve 683। Sayılı Orman Kanununun Bazı Maddelerinin Değiştirilmesine Dair Kanun

22.05.1987 683I Sayılı Orman Kanununun Bazı Maddelerinin Değiştirilmesi ve Bu Kanuna Bazı Hükümler Eklenmesi Hakkında Kanun

14.03.1989 Anayasa Mahkemesi Kararı

II.07.1994 Yargıtay Kararı

30.10.1995 4I27 sayılı, 2924 Sayılı Orman Köylülerinin Kalkınmalarının Desteklenmesi Hakkında Kanunun Bazı Maddelerinin Değiştirilmesi Hakkında Kanun

02.07.1996 Orman ve Orman Sınırı Dışına Çıkartılan Yerlerin Tescili Konulu Genelge

15.07.2004 683I Sayılı Orman Kanunu'na göre Orman Kadastrosunun Uygulanması Hakkında Yönetmelik

15.01.2009 583I sayılı Tapu Kanunu ile Bazı Kanunlarda Değişiklik Yapılmasına Dair Kanun

23.07.2010 6009 Sayılı Gelir Vergisi Kanunu İle Bazı Kanun Ve Kanun Hükmünde Kararnamelerde Değişiklik Yapılmasına Dair Kanun
"2/A maddesi kapsamındaki alanlar için yapılacak orman sınırı dışına çıkartma ile ilgili açılacak davaların bu kanuna göre yapılacak işlemleri durdurmaması, konuyla ilgili davalarda yürütmeyi durdurma ve ihtiyati tedbir kararı verilememesi" düzenlemesiyle sınır dışına çıkarmayı hızlandırması

Orman sınırları dışına çıkarılan alanların üzerinde bulunan yapılarla birlikte tespit edilerek mülkiyet devri ve bu mülkiyet üzerindeki yapılara yapı ruhsatı ve yapı kullanma izni verilmesi

İmar mevzuatına aykırı yapıların, imar mevzuatına uygun inşa edilerek yapı kullanma izni alınmış yapılar olarak kabul edilmesi (iptal) Orman Kanunu'nun 2/A ve 2/B maddelerinin yeniden düzenlenmesi ve özel kişiler adına orman sınırları dışına çıkartma işleminin mutlak olarak reddedilmesi

Orman sınırları içinde ve bitişiğinde bulunan tapulu, orman sınırları dışında ise her türlü tasarruf belgeleriyle özel mülkiyette bulunan ve tarım arazisi olarak kullanılan, dağınık veya yer yer küme ve sıra halindeki her nevi ağaç ve ağaçcıklarla örtülü yerler ile orman sınırları dışında olup, yüzölçümü üç hektarı aşmayan sahipli arazideki her nevi ağaç ve ağaçcıklarla örtülü yerlerin orman sayılmaması, Şehir, kasaba ve köy yapılarının toplu olarak bulunduğu yerlerdeki hususi orman alanlarında yatay alanın yüzde altısını (\% 6) geçmemek üzere imar planlamasına uygun inşaat yapılabilmesi

"Ne olursa olsun orman olarak sınırlandırılmış bir yer, artık ormandır".

"Orman sınırı dışına çıkartılan alanlarda zilyetlik yoluyla toprak kazanılamaz".

Orman sınırından çıkarılarak tarım alanına dönüştürülen yerlerin satışı konusunda düzenlemeler getirilmesi

Ormanda veya 2/B sahasında kalan taşınmaz malların tasarrufunun ayrı ayrı düzenlenmesi

Özel orman alanlarında da 2/B uygulamasının düzenlenmesi

33. madde ile orman sınırı dışına çıkarılacak yerlerin tanımlanması 2/B alanlarında ikinci kadastronun önünün açılması

Hazinenin 2/B arazilerini belediyelere devretmesi, belediyelerin bu arazilerin satışına olanak tanınması

Orman ve mera dışına çıkarılan alanlar dâhil kentsel ve kırsal alan ve yerleşmelerde yapılacak iyileştirme, yenileme ve dönüşüm uygulamalarında idarelerce uyulacak usul ve esasları belirlemek Çevre ve Şehircilik Bakanlığı'nın (Altyapı ve Kentsel Dönüşüm Hizmetleri Genel Müdürlüğü'nün) görevleri arasına girmesi 
Tablo 3 (devamı). Orman sınırı dışına çıkarma süreci

\begin{tabular}{|c|c|c|}
\hline Tarih & Mevzuat & Düzenleme \\
\hline 20.04 .2012 & $\begin{array}{l}6292 \text { sayılı Orman Köylülerinin Kalkınmalarının Des- } \\
\text { teklenmesi Ve Hazine Adına Orman Sınırları Dışına } \\
\text { Çıkarılan Yerlerin Değerlendirilmesi İle Hazineye Ait } \\
\text { Tarım Arazilerinin Satışı Hakkında Kanun }\end{array}$ & $\begin{array}{l}\text { 2/A alanlarının Orman Genel Müdürlüğü'nün, 2/B alanları ise } \\
\text { Maliye Bakanlığı'nın tasarrufuna geçmesi, bütüncül orman koru- } \\
\text { ma politikalarından uzaklaşılması } \\
\text { 2/B alanlarının satışa konu edilmesi } \\
\text { 2/B alanlarının ve çevrelerinin Proje Alanı ya da dönüşüm alanı } \\
\text { olabilmesi }\end{array}$ \\
\hline 31.05 .2012 & $\begin{array}{l}6306 \text { sayılı Afet Riski Altındaki Alanların Dönüşümü } \\
\text { Hakkında Kanun }\end{array}$ & $\begin{array}{l}\text { Orman alanlarını kentsel dönüşüm konusu etmesi (iptal) } \\
\text { Orman Kanunu'na eklenen I3. maddeyle ormanların afet sonra- } \\
\text { sında geçici barınma yeri olarak kullanılması için talepte bulunan } \\
\text { idarelerce altyapı hizmetleri verilmesi }\end{array}$ \\
\hline 20.11 .2012 & Orman Kadastrosu ve 2/B Uygulama Yönetmeliği & $\begin{array}{l}\text { Bir yerin kasaba ve şehir toplu yerleşim alanı olarak orman sı- } \\
\text { nırları dışına çıkarılabilmesi için gerekli koşulların tanımlanması }\end{array}$ \\
\hline 18.05 .2018 & $\begin{array}{l}7 \mid 43 \text { sayılı Vergi Ve Diğer Bazı Alacakların Yeniden } \\
\text { Yapılandırılması İle Bazı Kanunlarda Değişiklik Yapıl- } \\
\text { masına İlişkin Kanun (İmar Barışı) }\end{array}$ & $\begin{array}{l}\text { Orman alanlarının } 6292 \text { sayılı Kanuna göre daha önce Maliye } \\
\text { Bakanlığınca satılan taşınmazların rayiç bedelleri emsal alınarak } \\
\text { satışa konu edilmesi }\end{array}$ \\
\hline
\end{tabular}

Kaynak: Yazar tarafından üretilmiştir.

olarak başlamış, plan kararıyla oluşan sanayi bölgelerinin etrafı gecekondu alanlarıyla çevrilmiştir. 1954'te Avrupa yakası için hazırlanan sanayi planı, Mecidiyeköy-Levent, Mecidiyeköy-Şişli, Bomonti ve Kasımpaşa - Kâğıthane arasında kalan kesimleri sanayiye açmış; 1955'te yürürlüğe giren İstanbul Sanayi Planı ise Topkapı-Rami ve Levent'te yeni sanayi alanları belirlemiştir. Böylelikle kent, hızlı bir yayılma süreci içine girmiştir. Bu yapılaşma ve nüfus baskısını, üst ölçekli ulaşım kararları izlemiştir. 1950'lerden başlayarak benimsenen karayolu politikası, kentin sınırlarının hızla genişlemesine zemin hazırlamıştır. Ankara Asfaltı'nın (E-5 Karayolu)'nun yapımı, 1973 yılında I. Boğaz Köprüsü'nün yapımı ve hemen ardından çevre yollarının inşa edilmesi, bir yandan sanayi kuruluşlarının, bir yandan da konut alanlarının hızla bu yollar boyunca oluşmasına yol açmıştır. Boğaziçi Köprüsü ve çevre yolları, hızlı büyüme sonucunda kısa sürede kent içi ulaşım ağının omurgası haline gelmiştir. Mevcut ulaşım politikasının nüfus ve yapılaşma baskısı tetiklemesi, 1988 yılında 2. Boğaz Köprüsü’nün ve hemen ardından yeni çevre yollarının açılmasıyla mekana yansımıştır. Her iki köprünün açılması, İstanbul'un kuzeye doğru genişlemesine yol açmış Taşdemir ve Batuk (2010) böylelikle orman alanları üzerinde giderek daha büyük baskılar meydana gelmiştir (www.hkmo. org.tr/resimler/ekler/5f66a7cda6239I5_ek.pdf) (Şekil 2).

Gerekçesi transit trafiği kentin daha kuzeyine ötelemek olan Fatih Sultan Mehmet Köprüsü'nün bağlantı yolları üzerinde ve TEM Otoyolu'nun geçtiği bölgelerde, I I.856 hektar alan orman sınırları dışına çıkartılmıştır. Sultanbeyli ve Sarıgazi gibi yerleşmelerin oluşmasının zemini 2. Köprü ve TEM otoyolu güzergahı ile hazırlanmıştır.

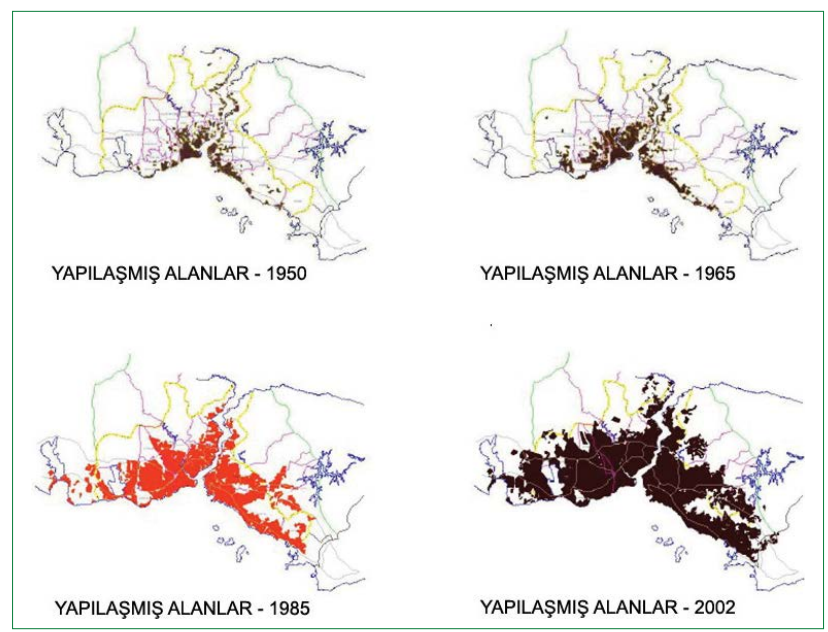

Şekil 2. 1975-2002 döneminde yapılaşmış alanlar. Kaynak: Çalışkan Ç. O., 20II.

Bu süreç içinde TÜiK verilerine göre Sultanbeyli'nin nüfusu 1980 yılında 243। kişi, 1980-85 arası dönemde nüfus 3.74| kişi, 1985-90 döneminde 82.000 kişi, 1985 yılında 3.700 kişi ve 1990yılında 82.300 kişi olmuştur. Bugün ise Sultanbeyli'nin nüfusu 286.622 kişiyi bulmuştur.

Aynı dönemde, birçok orman alanı, yapılaşma baskısı altında hızla orman vasfını kaybettiği gerekçesiyle orman sınırları dışına çıkartılmış; bu alanlar büyük bir rant sürecine zemin hazırlamıştır (Şekil 3).

1990'lı yıllarda birçok belde, birbiri ardına planlarla yapılaşmaya konu edilmiş, dönemin 3030 sayılı Büyükşehir Belediye 


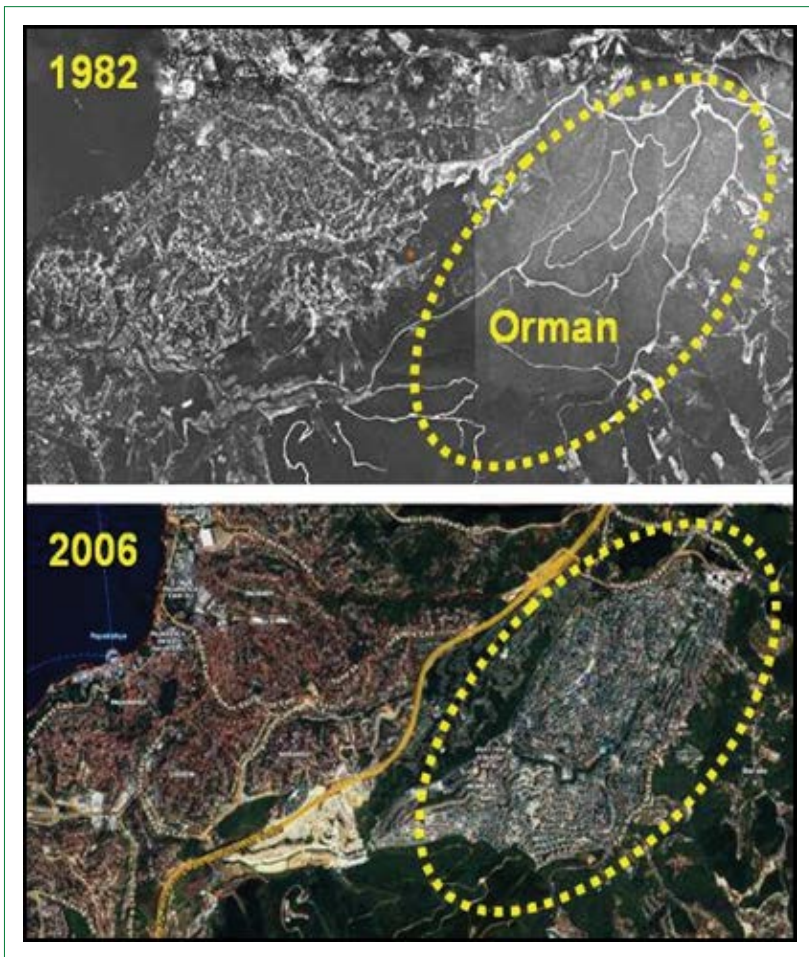

Şekil 3. Orman Alanlarının Yapılaşmış Alanlara Dönüşümü: Beykoz. Kaynak: Çalışkan Ç. O., 20II

Kanunu'na göre, Büyükşehir Belediyesi bu planlar üzerinde söz sahibi olmadığından dolayı, süreç hızla ve sorunsuz olarak işlemiş, orman alanları hızı bir şekilde 2/B alanlarına dönüşmüştür. Hiç kuşkusuz bu organize gelişim sürecini tetikleyen başka gelişmeler de mevcuttur. Özellikle bu bölgeleri de yakından ilgilendiren ulaşım kararları orman alanlarının hızla 2/B alanlarına dönüşmesinde büyük role sahiptirler. Bu durum, kenti içinde gerek I. Boğaziçi Köprüsü, gerekse 2. Boğaziçi ile somut olarak ispatlanmıştır. Kuzey ormanlarının yer aldığı bölgeleri de içine alan çevre yolu bağlantıları ve yeni ulaştırma politikaları da söz konusu beldelerde yapılaşma ve nüfus baskısı yaratan kararlardır. Yine kuzey ormanlarına doğru yer değiştirerek ilerlemekte olan MiA, yeni alışveriş merkezlerinin plan kararlarıyla bu bölgelerde türemeye başlaması gibi gelişmeler de süreç üzerinde büyük bir etkiye sahiptir. 15.06.2009 tarihli I/I00.000 ölçekli İstanbul Çevre Düzeni Planı'nın Açıklama Raporunda yer alan "Kentin doğal ve tarihi yapısını bozacak ve uzun dönemde ilave ulaşım sorunları oluşturacak ulaşım kararlarından kaçınılmıştır. İstanbul'un doğusu ile batısı arasında sürekliliği karayolu ile sağlanmış bir Boğaz geçişinin İstanbul'un kentsel gelişimi açısından olumsuz sonuçları, Fatih Sultan Mehmet Köprüsü geçişi sonrasında ortaya çıkan kentsel gelişme deseni ile deneyimlenmiştir. TEM Otoyolu boyunca kentin doğusu ile batısı arasında uzanan, yağ lekesi şeklinde büyüyerek doğal yapıyı tahrip eden, niteliksiz bir yapı stoku ve Sultanbeyli ve Sarıgazi gibi yerleşmeleri oluşturan süreçlerin tekrarlanmasına neden olacak gelişmelerin önüne geçilmesi hazırlanan Plan'da esas alınmıştır. Çünkü,
İstanbul'un doğal eşikleri benzer bir süreci yaşamayacak derecede hasar gördüğ̈unden, su toplama havza alanlarının ve ormanların daha fazla yok olmasına neden olacak gelişmelerden kaçııııması gerekmektedir" ifadesi, sorunu açık olarak ortaya koymaktadır.

Özellikle 2010'lardan sonra, bölgesel ölçekte bir mega projenin parçaları olan ve İstanbul'un ekolojik açıdan hassas bölgelerinde yer alan Üçüncü Köprü, Üçüncü Havalimanı ve Kanal İstanbul gibi projeler, Kuzey ormanları üzerinde büyük etkiler yapmışlardır ve yapmaya devam etmektedirler. İstanbul'un orman alanlarının daralmasına sebep olan bu süreci destekleyen yasal düzenlemeler de yapılmıştır. Kuzey Marmara (3. Boğaz Köprüsü Dahil) Otoyolu Projesi konulu 2016/20 sayılı Başbakanlık Genelgesi bunlardan biridir. 16 maddelik Genelgenin 6. maddesi, "Projenin gerçekleştirilmesi için gerekli olan Hazinenin özel mülkiyetinde veya devletin hüküm ve tasarrufu altındaki taşınmazlar ile ormanlık alanlar ile diğer kamu kurum ve kuruluşlarına ait taşınmazların KGM'nin talebi doğrultusunda tahsis, izin, irtifak, devir veya yola terkin işlemlerinin hızla yürütülebilmesi için gerekli önlemler ilgili idarelerce alınacak, bunun için gerekirse mevzuatı çerçevesinde ilgili idarelerin taşra birimleri de yetkilendirilerek gecikmeye mahal verilmeyecektir" şeklindedir. Bu maddeden de anlaşılacağı üzere, Üçüncü Köprü Projesi ile ormanlık alanların tahsisi, vb. kullanım yollarının önü açılmaktadır. Bu karara dayanarak, İstanbul'da 8 ilçede bazı alanlar için acele kamulaştırma kararı alınmıştır. Benzer şekilde, Üçüncü Havalimanın için de 20I4/5768 sayıl Bakanlar Kurulu kararı ile Arnavutköy İlçesi, İmrahor, Tayakadın ve Yeniköy köyleri ile Eyüp İlçesi, Ağaçlı, Akpınar ve İhsaniye köylerinde yer alan, ekli haritasında sınır ve koordinatları gösterilen alan içerisindeki taşınmazların, İstanbul 3. Havaalanı Projesi kapsamında Toplu Konut İdaresi Başkanlığı tarafından acele kamulaştırılması; Bakanlar Kurulu'nca 2/I/20I4 tarihinde kararlaştırılmıştır. Kararda bahsi geçen alanların büyük bir kısmı orman alanıdır.17.01.20I4 tarihinde Resmi Gazete'de yayınlanan 'acele kamulaştırma kararı'na karşı İstanbul Barosu, Yukarı Ağaçı̆ı köylüleri adına dava açarak TOKi'ye acele kamulaşırma yetkisi veren Bakanlar Kurulu kararı ve dayanağı 'kamu yararı' kararının iptalini istemiştir. Danıştay 6'ncı Dairesi, 9.06.2014 tarihinde kararın yürütmesinin durdurulmasını gerektirecek telafisi güç bir durumun bulunmadığı gerekçesiyle talebin reddine karar vermiştir. İstanbul Barosu'nun ret kararına yaptığı itirazı değerlendiren Danıştay İdari Dava Daireleri Genel Kurulu, 22.10.2014 tarihinde acele kamulaştırma işleminin yürütmesini durdurmuştur. Kararda, ancak yurt savunması ihtiyacı veya olağanüstü hallerde 'acele kamulaştırma'nın yapılabileceği vurgulanmıştır.

Üçüncü Köprü Projesinin bir parçası olan ve 26.000 hektar alanı kapsayan Kanal İstanbul Projesi de, Avrupa'nın acil korunması gereken 100 orman alanı arasında yer alan İstanbul ormanlarını tehdit etmektedir. Kanal İstanbul proje alanının en kuzeydeki $15-20$ km'lik bölümü orman alanıdır ve güzer- 
gahının büyük bir kısmı Çatalca Orman İşletmesi sınırları içinde yer almaktadır. Çatalca'da 107.000 hektarlık orman alanı tahrip edilecek, Terkos-Haliç-Çekmece ekolojik koridoru söz konusu proje ile yok olma riski ile karşı karşıya kalacaktır. WWF Raporu (20I5), Kanal genişliği 150 metre bile olsa -ki daha sonradan 250 metre olmasına karar verilmiştir- 300-350 hektar civarında orman alanının, yalnızca kanalın fiziki varlığı ile doğrudan ortadan kalkacağından söz etmektedir.

2/B alanlarında yer alan yapılaşmalar, birbirinden farklı özellikler göstermektedir. Orman içinde kalan ya da kalmayan, orman bütünlüğünü bozan ya da bu bütünlüğün dışında yer alan, vb. birçok farklı 2/B yerleşmesi söz konusudur. İstanbul'un 2010 yılında onaylanarak yürürlüğe giren $1 / 100.000$ ölçekli Çevre Düzeni Planı'nda, orman vasfını kaybetmiş alanlar böyle bir sınıflandırma içerisinde yer bulmuştur. Plan raporuna göre;

- Orman içerisinde kalan orman vasfını kaybetmiş alanların ekolojik olarak ormanla bütünleşmesinin sağlanması;

- Orman içerisinde olmayan, sürdürülebilirlik açısından ormanla bütünleştirilemeyen ve üzerinde yapılaşmanın olmadığı orman vasfını kaybetmiş alanların, tarım, rekreasyon ve ihtiyaç duyulan kamuya ait donatı alanları olarak değerlendirilmesi

- Orman içerisinde olmayan, sürdürülebilirlik açısından ormanla bütünleştirilemeyen ve üzerinde yapılaşmanın olduğu orman vasfını kaybetmiş alanlardaki yapılaşmanın rehabilite edilmesi gerekmektedir.

"Ormana yönelik gelişme baskısının engellenmesi” ilkesini kabul eden Plan raporunun hedefleri arasında, "kentin mekânsal anlamda kontrolsüz yayılmasını öngören, tarım topraklarını, su havzalarını, orman alanlarını tehdit eden planların çevresel sürdürülebilirlik ilkeleri göz önünde bulundurularak revize edilmesi” yer almaktadır. Planda, İstanbul'un donatı ihtiyacının karşılanması için yerleşme içinde kalan orman vasfını kaybettiği için orman sınırı dışına çıkartılan alanların değerlendirilmesi öngörülmektedir. Bu amacı gerçekleştirmek üzere, orman ile yerleşim yerleri arasında yer alan bu nitelikteki alanların, yerleşim alanlarının ormana olan baskııını azaltacak şekilde, ya ağaçlandırılarak ekolojik olarak ormanla bütünleştirilmesi ya da kentlinin intiyacını karşılayacak sosyal donatı alanı olarak planlanması hedeflenmektedir.

\section{Orman Sınırı Dışına Çıkartılmış Alanlar İçin Bir Yaklaşım Önerisi}

Orman sınırları dışına çıkartılmış alanlar sorunu, kentlerimizin birçoğunda olduğu gibi, İstanbul için de bir kronikleşmiş bir sorun olarak varlığını sürdürmektedir. Hiçbir siyasi irade bugüne dek sorunu gerçek anlamda çözme yolunda kalıcı adımlar atamamış, 2012 yılında İstanbul'da bunun ilk adımlarından biri atılsa da, çözüm, basit bir imar affının ötesine götürülmemiştir. Sorunun bugüne dek çözümlenememesinin ardındaki en büyük neden, orman sınırı dışına çıkartılan alanların tümü- ne aynı bakış açısıyla yaklaşarak sorunu bir bütün olarak çözmeye çalışmak olmuştur. Oysaki, kaotik gelişim süreci içinde bu alanların birbirinden farklı özelliklerle geliştiği, zeminlerini oluşturan planlama ve kurul kararlarına bağı ya da tümüyle yasadışı olarak farklı koşullarla ortaya çıktığı bilinmektedir.

Bu nedenle, 2/B sorununu çok boyutlu olarak ele almak, sınıflandırmak ve bu sınıflandırmanın şekillendirdiği planlama yaklaşımlarına ve çözümlere gitmek gerekmektedir. 2/B alanlarını, amaç ve kullanım türlerine, orman ve kent ile ilişkisine, yasal durumlarına ve planlama kararlarındaki konumlarına bakarak sınıflandırmaya tabi tutmak mümkündür (Tablo 2):

- Amaç ve kullanım türlerine göre; $2 / B$ alanları kullanım amacına göre konut, eğitim, tarım, sanayi gibi başlıklar altında sınıflandırılabilir. Bu alanlar içinde en fazla konut ve tarım alanları bulunmasına karşın, zaman zaman özel eğitim kurumları ve sanayi alanlarının da yer aldığı görülmektedir.

- Orman ve kent ile olan ilişkisine göre; $2 / B$ alanlarının kent ile olan ilişkisi, yapılacak sınıflandırmada önem taşımaktadır. Alanın kentin ve ormanın hangi bölgesinde yer aldığı ve planlama sistemi içerisinde bu ilişkinin ne şekilde kurgulandığı saptanmalıdır.

- Orman bütünlüğünü bozan 2/B alanları: Orman alanının içinde, münferit olarak oluşmuş ve orman bütünlüğünü açık bir şekilde bozan, zedeleyen yerleşim alanlarının, ivedilikle ortadan kaldırılması ve bu alanların ormana geri kazandırıması sağlanmalıdır (Şekil 4, 5).

- Mevcut yerleşimle bütünleşmiş 2/B alanları: Kronik hale gelmiş 2/B alanlarıdırlar. Bu alanlar zaman içinde büyüyüp yayılmış, kentsel sistemin bir parçası haline gelmişlerdir. Yayılmanın boyutları büyüktür ve nüfus yoğunluğu bir orman yerleşmesinde bulunması olanaksız olan boyutlardadır. Bu alanların kentle güçlü ilişkileri mevcuttur ve alanın üzerinde yer alan yapı yoğunluğu ve nüfusun tekrar orman alanına dönüşmesi hemen hemen mümkün değildir (Şekil 6, 7).

- Amacı ve kullanım türüne göre (tarım gibi) ayrılmış 2/B alanları: Orman alanları içinde, konut alanları dışında farklı kullanım türleri de mevcuttur. Maden ocakları, eğitim kurumları, bazı sanayi işletmeleri, tarım alanları, vb. birçok kullanım türü, orman alanlarının içinde faaliyetlerini aktif olarak sürdürmektedirler (Şekil 8, 9).

2/B alanlarının konumuna, kent ile ilişkisine, planlama kararlarına bakarak, üç temel müdahale yönteminden söz etmek mümkündür:

- Yıkarak ormana kazandırma: Plan kararı ile oluşsun ya da oluşmasın, orman bütünlüğünü tehlikeye atan münferit 2/B alanlarıyla ilgili olarak yapılması gereken, bu alanları ivedi olarak yıkıp, ormana geri kazandırmaktır. Bu müdahale yönteminde yapılacak işlerin bütçesi, plansız alanlar için mülk sahiplerinden, planlı alanlarda ise kamu tarafından karşılanmalıdır. 


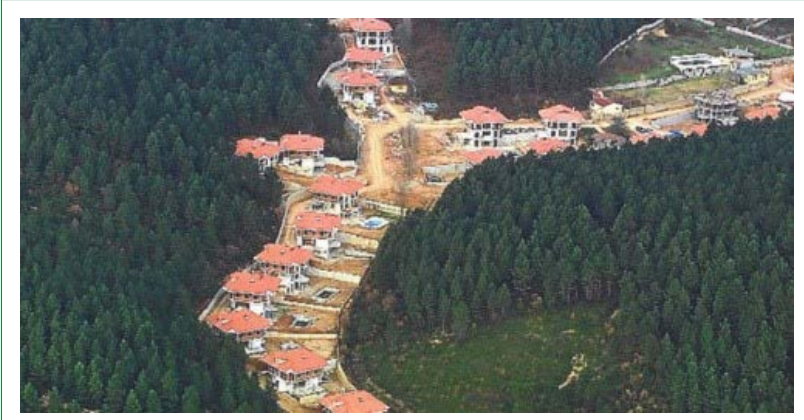

Şekil 4. Dere yatağı üzerindeki orman içi yerleşmeler (Kaynak: http:// www.sehiremlak.com/emlak-haberleri/2b-arazi-nedir-2b-arazilerininsatisi.htmlme alanı).

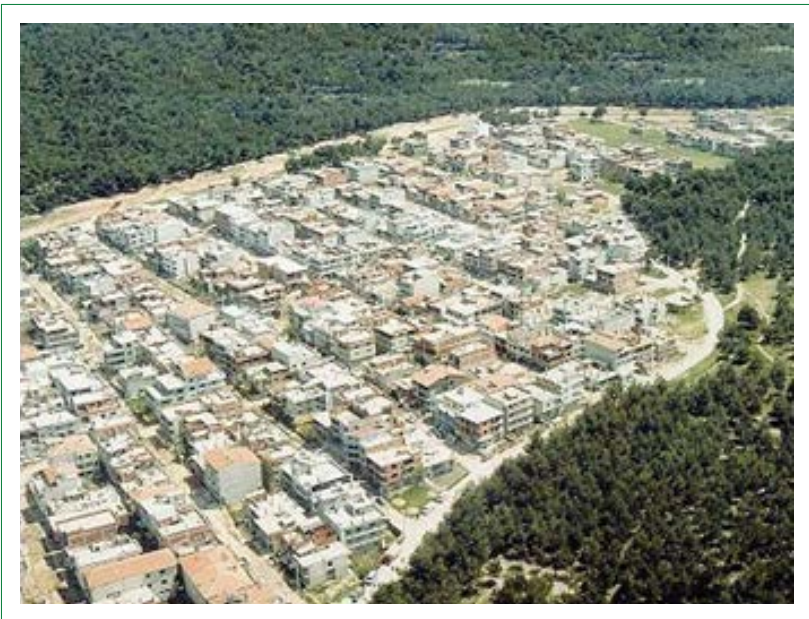

Şekil 5. Orman bütünlüğünü bozan yoğun yapılaşmış alanlar (Kaynak: http://www.mimdap.org/?p=1006).

- Rehabilitasyon: Plan kararı ile oluşmuş ve mevcut yerleşimle bütünleşmiş alanların mevcut koşullar gözönüne alınmak suretiyle rehabilite edilmesi gerekmektedir. Bu tür alanlarda, rehabilitasyon bütçesi, bir ortaklık modeliyle oluşturulabilir. Bu alanlar içerisinde orman alanına katılabilecek kısımlar varsa tespit edilmeli, gerekirse bir ayıklama ve temizleme yönteminden de yararlanılmalıdır. Geri kalan alanların ise, planlama bütünlüğü içindeki yeri belirlenmeli, orman sınırlarını daha fazla daraltacak, yapı ve nüfus baskısı oluşturması muhtemel plan kararları gözden geçirilmeli, uzun vadede bu alanların yeniden orman alanına dönüşmesine olanak tanıyacak ve kademeli bir şekilde yapı ve nüfus yoğunluğunu azaltacak plan kararları getirilmelidir. Orman sınırlarına çok yakın olması nedeniyle orman alanları için bir tehdit oluşturabilecek kullanım türleri kısa vadede sınırlandırılmalı ve daha uzun vadede ise plan kararı ile ortadan kaldırımalıdır. Böylece, bir etaplama yapmak suretiyle, gerek konut alanları, gerekse diğer kullanım türleri için yumuşak bir geçiş süreci üretilmeli ve süreç içindeki adımlar, zamana yayılarak, plan kararları içinde absorbe edilmelidir.

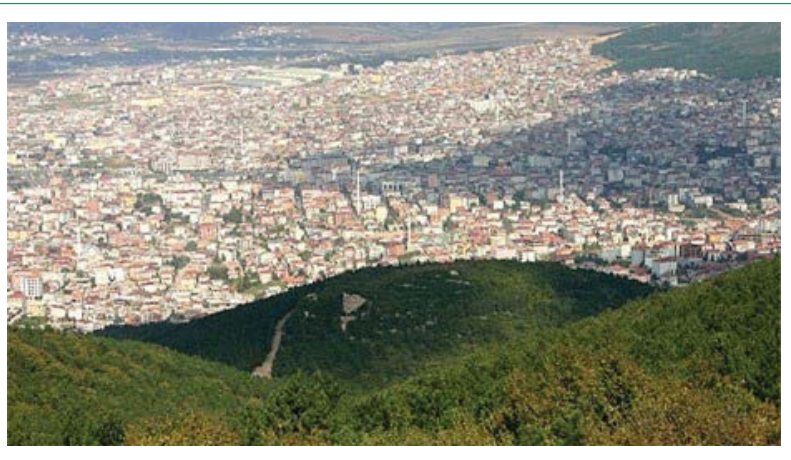

Şekil 6. Sultanbeyli'de 2/B alanları (Fotoğraf: Anonim).

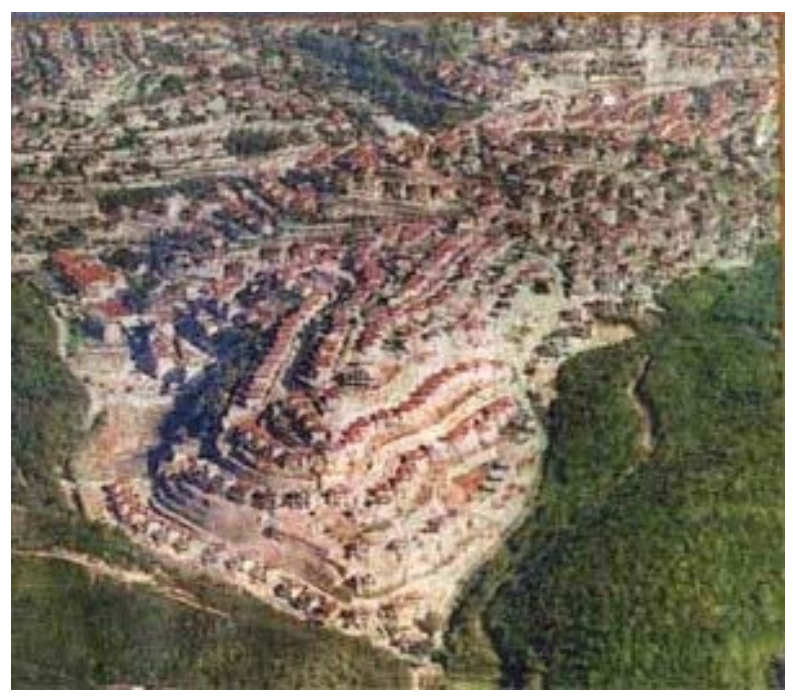

Şekil 7. Kentle bütünleşen yapılaşmış alanlar (Fotoğraf: Anonim).

- Kentsel Dönüşüm: Plan kararı ile oluşmamış, kent ile bütünleşmiş, sağılıksı bir üretim süreci ile oluşmuş ve boyutları, yapı ve nüfus yoğunluğu itibariyle ormana geri dönüşümü mümkün olmayan alanlar için kentsel dönüşüm yöntemine başvurulmalıdır. Bu durumda, kamu ve özel sektör işbirliği ile üretilecek bir dönüşüm modeline ihtiyaç bulunmaktadır. Dönüşüm modeli, piyasa aktörlerine bir pazar açma yaklaşımı ile oluşturulmamalı, gerçek anlamda katılım mekanizmalarının işler kııındığı, kar amacının asgari düzeyde tutulduğu ve temel amacın, "orman alanları üzerindeki daha fazla yapı ve nüfus baskısını ortadan kaldırmak" olduğu bir yaklaşım ile üretilmelidir. Bu alanların herhangi bir gecekondu dönüşüm alanı olmadığı ve sorunun bu bakış açısıyla çözülemeyeceği gerçeği en temel kabul olarak alınmalıdır.

Bu perspektiften bir yaklaşımla sorunu basit bir şekilde şematize ederek şöylece tanımlamak mümkündür:

Bu basit şematik rehberin izlenmesi ile, atılacak adımların büyük ölçüde "yıkarak geri kazandırma" yolunu işaret ettiği 


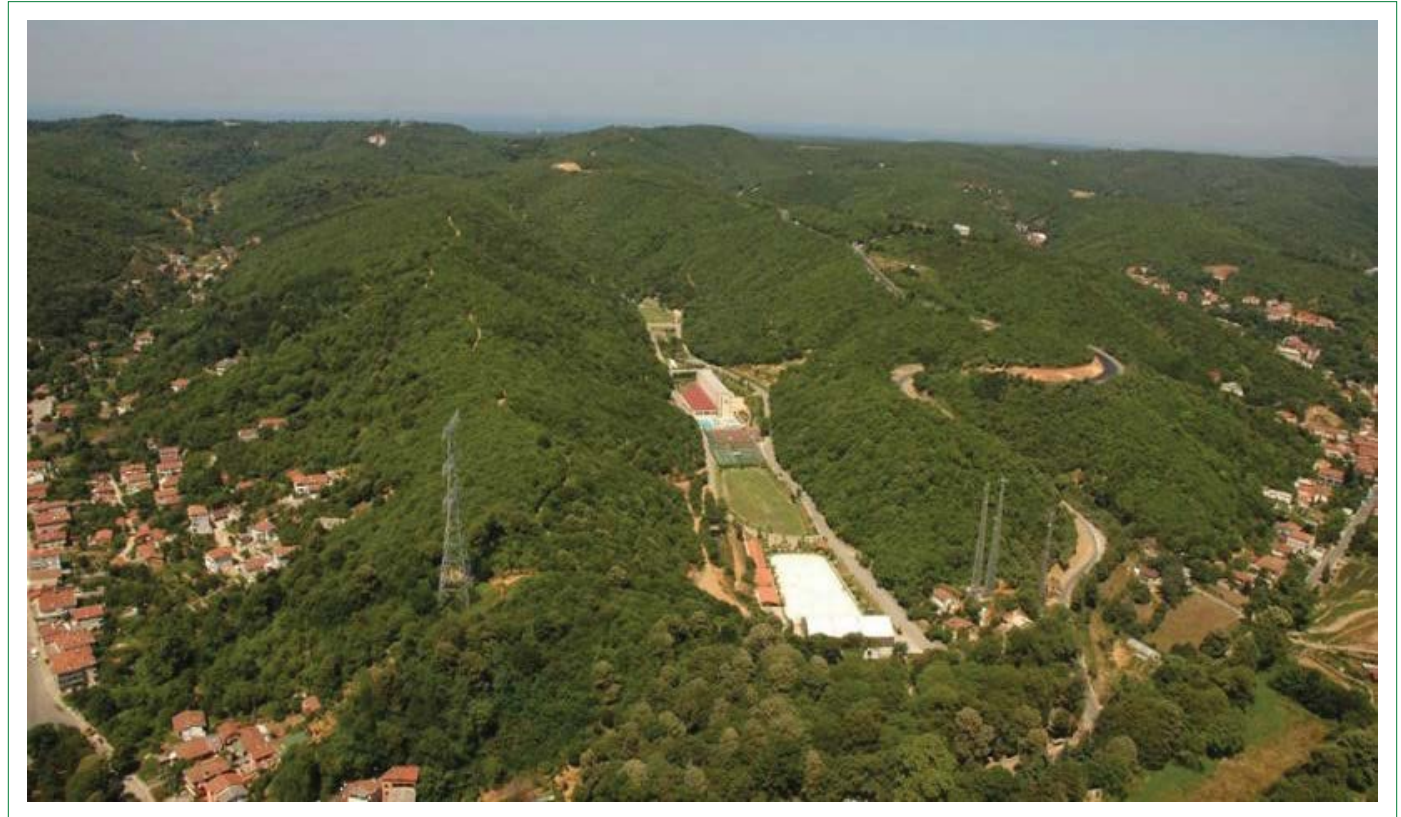

Şekil 8. Beykoz ormanları içinde 2/B arazisinde özel bir eğitim kurumu (Fotoğraf: Anonim).

görülmektedir. Bununla birlikte, rehabilitasyon gibi ikincil müdahale yöntemi ya da kentsel dönüşüm gibi sınırlı durumda başvurulması gerekli yöntemlerin, bu alanların büyüklüğü ve yoğunluğu dikkate alındığında çok daha geniş kapsamlı ve uzun vadeli işlemler olduğunu gözden kaçırmamak gerekmektedir. Birinci yol teknik olarak belki de en kolay yoldur. Ancak rehabilitasyon ve dönüşüm yolları, gerek ekonomik, gerek sosyal, gerekse fiziksel anlamda önemli ve karmaşık sorunları da beraberinde getirecektir. Dolayısıyla yasal sorunlar da sürecin önemli bir adımını oluşturacaktır.

Bu anlamda, 2/B alanları için geliştirilecek önerileri birkaç başlık altında sıralamak mümkündür:

\section{I. Yasal Açıdan}

En önemli konu, uzun vadede yeni Anayasal ve yasal düzenlemelerle 2/B alanı kavramına son verilmesidir. Orman tanımından yola çıkarak, ormanın "vasfını gerçekte kaybetmeyen bir varlık” olduğu gerçeğine odaklanarak, bozulan orman arazilerinin hızla eski vasfına geri kazandırılması yasal düzenlemelerde yerini almalıdır.

Farklı yasalarla 2/B sorununu daha da derinleştirecek istisnaların getirilmesi engellenmelidir.

\subsection{Yönetsel Açıdan}

Orman alanlarına yönelik yetkiler, farklı kurumların görev ve yetki alanları içinde tanımlanmamalıdır. Bu şekildeki bir yetki paylaşımı, bütüncül bir koruma anlayışının benimsenmesi yerine, eşgüdümsüz ve parçacıl uygulamaları teşvik etmektedir.
Tablo 4. İstanbul ilçelerinde 2/B alanları

\begin{tabular}{lc}
\hline İçe & 2/B arazisi $\left.\mathbf{( m}^{\mathbf{2}}\right)$ \\
\hline Beykoz & 26.700 .000 \\
Şile & 18.400 .000 \\
Çatalca & 16.870 .000 \\
Silivri & 14.700 .000 \\
Sultanbeyli & 4.937 .000 \\
Ümraniye & 4.515 .000 \\
Çekmeköy & 4.756 .000 \\
Pendik & 3.215 .000 \\
Arnavutköy & 2.900 .000 \\
Eyüp & 1.985 .000 \\
Sarıyer & 1.908 .000 \\
Sancaktepe & 763.500 \\
Üsküdar & 550.000 \\
Şişli & 535.000 \\
Tuzla & 212.000 \\
Maltepe & 110.000 \\
Kağıthane & 85.000 \\
Kartal & 35.000 \\
\hline Kaynalsta
\end{tabular}

Kaynak: İstanbul deftarlı̆ı koordinasyonunda Tapu Kadastro ve Milli Emlak Bölge Müdürlükleri çalışma grubu verileri. http://www.abgazetesi.net/haber/38/4/-2barazilerde-son-durum.html

\subsection{Planlama Açısından}

Üst ölçekli plan kararlarının uygulanması ve bu kararların orman alanları için de işletilmesinin sağlanması, büyük önem taşımaktadır. Farklı mevzuat kapsamında üst ölçekli plan kararlarının delinmesi yeni bir konu değildir ancak orman alanları gibi 


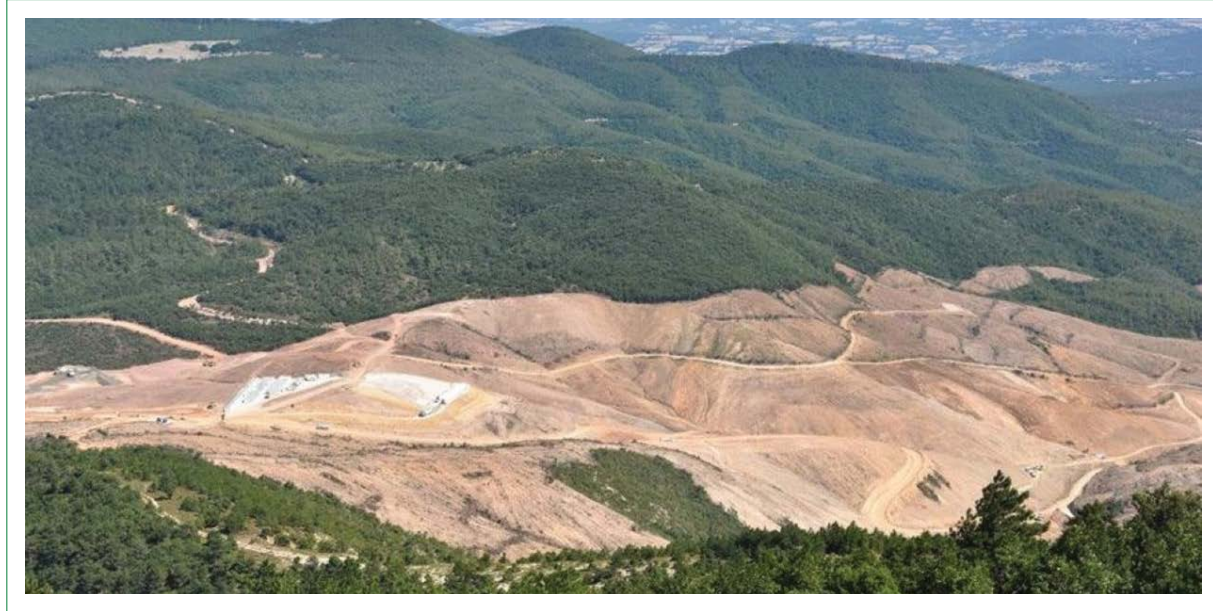

Şekil 9. Kaz Dağlarındaki madencilik faallyetleri (Kaynak: https://kuzeyormanlari.org/2019/08/04/nurolholding-kaz-daglarindaki-altin-madeniyle-ilgili-riskleri-yerli-cedde-gizledi-avrupa-bankasina-verdigi-cedde-yazdi/).

kentlerin temel doğal yaşam alanları olan bölgeler açısından hayati önem arz etmektedir.

2/B alanlarının zaman içinde geldiği farklı noktalara dayanarak yapılacak bir sınıflandırma ile, her birine özel planlama kararları geliştirilmesi sağlanmalıdır.

\section{Sonuç ve Değerlendirme}

Orman sınırları dışına çıkartılmış alanlar sorunu, çok başı ve çok boyutlu bir süreci beraberinde getirmektedir. Söz konusu alanların birbirinden farklılığı, sorunu daha da kapsamlı hale getirmekte, çözüme ulaşmayı güçleştirmektedir. Bu çözümsüzlükler yumağı içinde,

- Sorunu çözme adına ardı ardına gelen ve daha fazla kaos yaratan yasal düzenlemeler,

- Sorunun farklı boyutlarının bir arada ele alınmaması ve konuya bütüncül bir çerçevedenve geniş bir perspektiften yaklaşıımaması,

- Planlama kararlarının bu tür alanları bir öncelik olarak ele almaması,

- Kent, planlama, ulaşım ve orman ilişkisinin kurulamaması,

- Sorunun çok boyutlu alt başlıklarının içlerinin yeterli sayıda uzman ile doldurulamaması,

sorunu içinden çıkılmaz bir noktaya taşımıştır. Bununla birlikte, bu alanların çözümsüzlüğe bırakılması da beklenemez. Dolayısıyla, yapılması gereken, sorunu öncelikle özel koşulları çerçevesinde parçalara ayııı her parça için geniş katılımlı çözüm arayışların geliştirmek, daha sonra bu parçaları, en tepedeki "orman alanlarını koşulsuz olarak koruma ve sürdürülebilir kılma" hedefi çerçevesinde bir araya getirip uyumlaştırma olmalıdır. Aksi takdirde, orman sınırları dışına çıkartılan alanlardaki fiziksel, sosyo-ekonomik ve yasal sorunların büyüyerek artması kaçınılmaz olacaktır.

Daha önce de belirtildiği üzere, Anayasa'nın 169. Maddesine göre, devlet ormanlarının mülkiyeti devrolunamaz. Bu ormanlar zamanaşımı ile mülk edinilemez. Ormanlara zarar verebilecek hiçbir faaliyet ve eyleme müsaade edilemez. Ormanların tahrip edilmesine yol açan siyasî propaganda yapılamaz; münhasıran orman suçları için genel ve özel af çıkarılamaz. Ormanları yakmak, ormanı yok etmek veya daraltmak amacıyla işlenen suçlar genel ve özel af kapsamına alınamaz. Bununla birlikte, Anayasaya ve Anayasa Mahkemesi kararlarına aykırı oldukları bilinmesine karşın, 2/B alanlarının, orman sınırları dışına çıkarıldıkları tarihteki fiili kullanım durumlarına göre ifraz edilerek, üzerinde yapısı bulunanlara satılması için birçok yasa çıkarılmıştır (Köktürkve Köktürk, 2004).

Özellikle de İstanbul gibi, 2/B alanları üzerinde yapılaşma baskısının çok büyük olduğu kentlerde sorunun daha da ivedilikle ele alınması, üst ölçekli planlarda bu konuda temel yaklaşımların geliştirilmesi ve yasal açıdan güçlü yaptırımlar getirilmesi kentler için kaçınılmaz bir önceliktir.

Bu çerçevede;

- Kısa vadede: Sürdürülebilir bir orman politikası oluşturmak ve ilkeler belirlemek üzere ilgili disiplinlerle eşgüdümlü, disiplinler arası çalışmalar yürütülmesi, müdahalelere yönelik yeni ortaklık ve bütçe modellerinin belirlenmesi

- Orta vadede: ormanların satış, kapsamın daraltılması, tahsis, kirama gibi yollarla yapılaşmaya açılmasına izin vermeyecek şekilde ilgili yasalarda düzenlemeye gidilmesi, orman alanlarının 2/B alanına dönüştürülmemesi amacıyla en başından itibaren tedbir alınması, denetim yapılması

- Uzun vadede: Geri dönüş imkanı olan alanların tekrar ormana kazandırılması için gerekli planların ve yasal düzenlemelerin hayata geçirilmesi yönünde adımlar atılmalıdır.

Orman politikasının ve uygulamalarının merkezi ve yerel yönetimlerin ortak sorumluluğunda ve işbirliğinde yürütülmesi büyük önem taşımaktadır. 


\section{KAYNAKLAR}

Acun E., Ormanın Kara Kitabı, İBB İstaç Yay., 4, İstanbul, 1998

Anbar Ö. A., Orman Tahdit Haritaları Doğrultusunda Tapu ve Kadastro İşlemleri, Orman Kadastrosu ve 2/B Sorunu Sempozyumu 17-18 Eylül 2004, Bildiriler ve Panel Kitab1, TMMOB Harita ve Kadastro Mühendisleri Odası Yay., İstanbul, 2004, s. 17-28

Atbaşoğlu F., Orman Kanununun 2/B Maddesinin Uygulanması ve Değerlendirilmesindeki Sorunlar Paneli, TMMOB Orman Mühendisleri Odası, Ankara Şubesi, Ankara, 2003.

Atmış E., Günşen H. B., Political parties and forestry relations in Turkey's general elections in 2015, Journal of the Faculty of Forestry Istanbul University 2016, 66(2): 587-599

Ayanoğlu S., Hukuksal Açıdan Orman Emlakı ve Orman Mülkiyetinin Temelleri, İ.Ü., FBE., Doktora Tezi, 1985

Başpınar V., Orman Sınııının Dışına ÇıkarılanYerlerin Hukuki DurumuAnkara Üniversitesi Hukuk Fakültesi Dergisi, Cilt: 48 Sayı: 1 Yayın Tarihi: 1999, s. 187-212

Çağlar, Y., 2015. Siyasal Partiler Ormancllı̆ımız ile Ormanlarımızda da Havanda Su Dövüyor, Ormanlar ve Ormancilık Üzerine Sessiz Tartışmalar Serisi.

Erdönmez, C., Atmıs, E., Özden, S. 2010. Türkiyéde Ormancılık Politikası, Ormancılık Politikası, Türkiye Ormancılar Derneği Eğitim Dizisi Yayın No. 6, 102-146.

Erdönmez, C., 2/B Alanlarının Satışının Türkiye Ulusal Ormancılık Programı Açısından İrdelenmesi Kastamonu Üniversitesi., Orman Fakültesi Dergisi, 2013, 13 (2): 307-324

Gençay G. Ş., Genel Kadastro-Orman Kadastrosu İlişkileri Konusundaki Son Düzenlemelerin Hukuksal Açıdan Değerlendirilmesi, I. Ormancılıkta Sosyo-Ekonomik Sorunlar Kongresi 19-21 Şubat 2009, SDÜ, Isparta, 412-421

Gülöksüz E., Doğal Kaynağa Dayalı Sermaye Birikimi ve Orman Sayılan Alanlarda Mülkiyet Hakları, Memleket Siyaset Yönetim, C: 5, Sa: 12, 2010/12, s. $70-89$

Keleş R., Hamamcı C., Çoban A., Çevre Politikası, Geliştirilmiş 6. Baskı, İmge Kitabevi Yay., Ankara, 2009

Köktürk E., Köktürk E., Orman Kadastrosu Ve “2/B” Gerçeği, Orman Kadastrosu Ve 2/B Sorunu Sempozyumu, Ylldı Teknik Üniversitesi Oditoryumu, İstanbul 17 - 18 Eylül 2004, 90-120

Ovalıoğlu S., Danıştay Kararları Işı̆̆ında Üstün Kamu Yararı, Memleket Siyaset Yönetim (MSY), Cilt 10, Sayı 24, Temmuz 2015, s. 124-146.

Şimşek S., Ormanlar Üzerindeki Bazı Mülkiyet Uyuşmazlıkları ve Bunlara İlişkin Çözüm Önerileri, Sayıștay Dergisi Sa: 79, Ekim - Aralık 2012, s. 127-156

Torun S., 2/B Yasası Beklentileri Karşıladı mı?, Denetişim 2013/12, 80-83

Turan M., ve Bayram M., Toprağın Menkulleştirilmesi, Memleket Siyaset Yönetim, C: 5, Sa: 12, 2010/12, s. 90-101

Teknik Raporlar ve Basın Açıklamaları:

Çalıskan Ç. O.,3. Boğaz Köprüsü Değerlendirme Sunumu, TMMOB Şehir Planciları Odası İstanbul Şubesi, Aralık 2011

2/B Sorunu: Gerçekler, Öneriler, TMMOB Yay. Nisan Ankara, 2006

İstanbul 1/100 000 Ölçekli Çevre Düzeni Plan Raporu

“Orman Alanları İmar Affiyla Satıliyor", TMMOB Harita Ve Kadastro Mühendisleri Odası İstanbul Şubesi Yönetim Kurulu Basın Açıllaması, 2009

Ya Kanal Ya İstanbul, Kanal İstanbul Projesinin Ekolojik, Sosyal ve Ekonomik Değerlendirmesi, WWF, 2015

\section{Internet Kaynakları}

Ormancıllk İstatistikleri 2010, orman ve Su İșleri Bakanlığı Resmi İstatistik Programı Yayın, http://web.ogm.gov.tr/Dkmanlar/istatistikler/ormancilik_ist_2010.pdf (Erişim tarihi: 15 Haziran 2012) http://www.milliemlak.gov.tr/web/guest/istatistiksel-bilgiler (Erişim tarihi: 09 Haziran 2012)

İstanbul Defterdarlığı koordinasyonunda Tapu Kadastro ve Milli Emlak Bölge Müdürlükleri çalşsma grubu verileri. http://www.abgazetesi.net/ haber/3814-2b-arazilerde-son-durum.html (Erișim tarihi: 05Temmuz 2012)

Karaca M, 2/B Sorunu ve 6292 Sayll Kanunla Getirilen Düzenlemeler, Maliye Uzmanlar Der., 78-87 (erişim tarihi: 07 Ocak 2017)

Taşdemir İ., Batuk F., Boğaz Geçişlerinin İstanbul'un Mekansal Gelişimine Etkileri, 2010, http://www.hkmo.org.tr/resimler/ekler/5f66a7cda623915_ ek.pdf (Erişim tarihi: 05 Ocak 2017) 